GEAP-10140

AEC RESEARCH AND DEVELOPMENT REPORT

JANUARY 1970

\title{
THE EFFECT OF CYCLIC STRAIN AGING ON THE EMBRITTLEMENT OF A PLAIN CARBON STEEL PLATE
}

\author{
A.J. BROTHERS \\ D.A. WOODFORD \\ MATERIALS AND PROCESSES LABORATORY \\ SCHENECTADY, NEW YORK
}

U.S. ATOMIC ENERGY COMMISSION

CONTRACT AT(04-3)-189

PROJECT AGREEMENT 37

THIS DOCUMENT CONFIRMED AS

UNCLASSIFIED

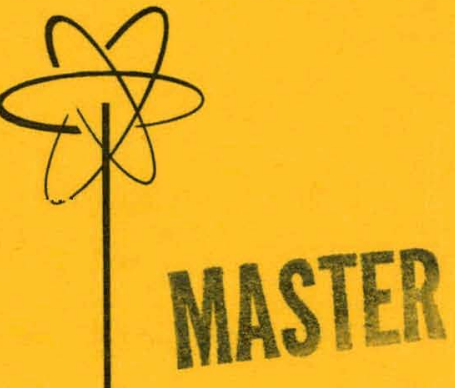

DIVISION OF CLASSIFICATION 


\section{DISCLAIMER}

This report was prepared as an account of work sponsored by an agency of the United States Government. Neither the United States Government nor any agency Thereof, nor any of their employees, makes any warranty, express or implied, or assumes any legal liability or responsibility for the accuracy, completeness, or usefulness of any information, apparatus, product, or process disclosed, or represents that its use would not infringe privately owned rights. Reference herein to any specific commercial product, process, or service by trade name, trademark, manufacturer, or otherwise does not necessarily constitute or imply its endorsement, recommendation, or favoring by the United States Government or any agency thereof. The views and opinions of authors expressed herein do not necessarily state or reflect those of the United States Government or any agency thereof. 


\section{DISCLAIMER}

Portions of this document may be illegible in electronic image products. Images are produced from the best available original document. 
LEGAL NOTICE

This report was prepared as an account of work sponsored by the United States Government. Neither the United States nor the United States Atomic Energy Commission, nor any of their employees, nor any of their contractors, subcontractors, or their employees, makes any warranty, express or implied, or assumes any legal liability or responsibility for the accuracy, completeness or usefulness of any information, apparatus, product or process disclosed, or represents that its use would not infringe privately owned rights.
GEAP. 10140

AEC Research and

Development Report

January 1970

THE EFFECT OF CYLIC STRAIN AGING ON THE EMBRITTLEMENT OF A PLAIN CARBON STEEL PLATE

A. J. Brothers

D. A. Woodford

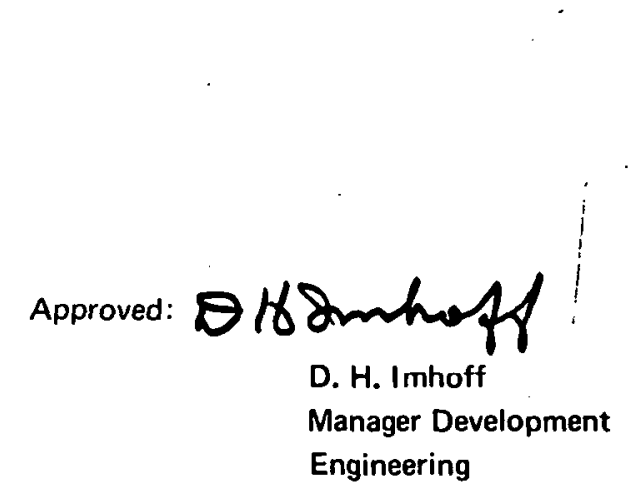

Approved: , , , tllut. ,

S. R. Vandenberg Project Engineer

Prepared for the

U.S. Atomic Energy Commission

Contract AT (04-3)-189

Project Agreement 37

Printed in U. S. A. Available from the

Clearing House for Federal Scientific and Technical Information

National Bureau of Standards, U. S. Department of Commerce

Springfield, Virginia

Price $\$ 3.00$ per copy

, $\quad$,

ATOMIC POWER IEQUIPMENT DEPARTMENT - GENERAL ELECTRIC COMPANY

San Juse, Califuruia 95125

\section{GENERAL ELETRIC}




\section{LEGAL NOTICE}

This report was prepared as an account of Government sponsored work. Neitber the United States, nor the Commission, nor any person acting on bebalf of the Commission:

A. Makès any warranty or representation, expressed or implied, witb respect to the accuracy, completeness, or usefulness of the information contained in this report, or that the use of any information, apparatus, method, or process disclosed in this report may not infringe privately owned rights; or

B. Assumes any liubilities with rospect to the use of, or for damages resulting from the use of any information, apparatus, metbod, or process disclosed in this report.

As iused in the abuve, "person scting on bohalf of the Commission" incliules any employes or contrartit of ibe Cummission, or emsployee of such crniractor, to the extent that such employee or contractor of the Commission, or employee of sucb coitiditior prepares, disseminates, or provides access to, any information pursuant to bis employment or contract with the Commission, or bis employment with such contractor. 
TABLE OF CONTENTS

1. Introduction ..... . . . . . . . . . . . . . . . . . . . . . . . 1

2. Review of Previous Work . . . . . . . . . . . . . . . . . . . . . . . . . . . 1

3. General Testing Plan . . . . . . . . . . . . . . . . . . . . . . . . . . 2

3.1 Strain Aging in Static Tensile Tests . . . . . . . . . . . . . . . . . . . . . . . . . . . . . 2

3.2 Embrittlement Following Strain Aging in Cyclic Tension-Compression Tests . . . . 2.

3.3 Locally Induced Embrittlement in Notch Bend Tests . . . . . . . . . . . . . 3

4. Experimental Procedures . . . . . . . . . . . . . . . . . . . . . . . . . 3

4.1 Materials and Test Specimens . . . . . . . . . . . . . . . . . . . . . . 3

4.2 Mechaniral Test Proredures .. . . . . . . . . . . . . . . . . . . . . . . 3

5. Experimental Results . . . . . . . . . . . . . . . . . . . . . . . . . . . . . 8

5.1 Strain-Aging in Static Tensile Loading . . . . . . . . . . . . . . . . . . . . . 8

5.2 Strain-Age Embrittlement in Cyclic Loading . . . . . . . . . . . . . . . . . . . . . . . . 8

5.3 Effect of Local Embrittlement in Notch Bend Tests . . . . . . . . . . . . . . . . . . . . . 8

6. Discussion . . . . . . . . . . . . . . . . . . . . . . . . . . . 19

7. Summary and Conclusions . . . . . . . . . . . . . . . . . . . . . . . . . . . 22

References . . . . . . . . . . . . . . . . . . . . . . . . . . . . . 22

\section{APPENDIX}

A. Electron Microscopy of Strain-Aged Plain Carbon Steel . . . . . . . . . . . . . . . . 23

References . . . . . . . . . . . . . . . . . . . . . . . . . . 24

Distribution . . . . . . . . . . . . . . . . . . . . . . 30 


\section{LIST OF ILLUSTRATIONS}

1 Microstructure of A-212B Carbon Steel Plate Used for Strain-Aging Experiments . . . . . . . . . . . . . . . . . . . . . . . . . 5

Configuration of Test Specimens . . . . . . . . . . . . . . . . . . . . . . . . . . . . . . 6

4 Load-Extension Curves for Carbon Steel (A212B) Specimens at $0.010 \mathrm{In} . / \mathrm{In} . / \mathrm{Min}$ Illustrating Serrated or "Śaw-Tooth"

Curve in Strain-Aging Temperature Range

5 Effect of Test Temperature on Ductility and Strength of A-212B Steel Tested in Tension at Various Strain Rates

6 Typical Charpy Impact Curves . . . . . . . . . . . . . . . . . . . . . . . . 12

7 Effect of Test Temperature on Charpy Impact and Static Tensile Properties . . . . . . . 13

8 Effect of Cyclic Strain at Various Number of Cycles to Shift the Charpy $50 \%$ FATT-Reference Condition $50 \%$ FATT $=0^{\circ} \mathrm{F}$. . . . . . . . . . . . . . 14

9 Effect of Cycle Strain, Test Temperature and Number of Cycles on Charpy $50 \%$ FATT-Reterence Condition 50\% FATT $=0^{\circ} \mathrm{F} \quad$. . . . . . . . . . . . . . 15

10 Notch Bend Strength at Fracture as a Function of Temperature for Pre-Cyclically Strain-Aged Specimens . . . . . . . . . . . . . . . . . . . . 17

11 Load-Deflection Curves for Notch Bend Tests . . . . . . . . . . . . . . . . . . 18

12 Correlation of Increase in 50\% FATT with Cyclic Strain History Parameter . . . . . . 20

13 Correlation of Charpy 50\% FATT with Total Cyclic Strain Range Illustrating Hardness Changes - See Figure 8 . . . . . . . . . . . . . . . . . 21

A-1 Relief Replicas Taken From Close to Fracture of Specimens Deformed in Tension at A) RT B) $300^{\circ} \mathrm{F}$ and C) $490^{\circ} \mathrm{F} \quad$. . . . . . . . . . . . . . . . . . . . . . . 25

A-2 Effect of Temperature on Dislocation Arrangement After Tensile Deformation. A) RT 20\% B) $300^{\circ} \mathrm{F} \sim 10 \%$ C) $490^{\circ} \mathrm{F}-15 \%$. . . . . . . . . . . . 26

A-3 Cell Formation Following Fatigue at $350^{\circ} \mathrm{F} \mathrm{A)} 37$ Cycles at $1.5 \%$ B) 200 Cycles at $0.5 \%$ C) 200 Cycles at $0.38 \%$. . . . . . . . . . . . . . . 27

A-4 Cell Formation Following Fatigue at RT for 20 Cycles at $0.5 \%$. . . . . . . . . . . . 28

A-5 Elongated Cells Formed After Fatigue at $490^{\circ} \mathrm{F}$ for 200 Cycles at $0.5 \%$. . . . . . . 29 


\section{LIST OF TABLES}

Table Title

Page

1 Composition and Mechanical Properties of Experimental Steels . . . . . . . . . . . 4

2 Tensile Properties of Carbon Steel (A-212B Plate) _. . . . . . . . . . . . . . . . 10

3 Charpy Impact Properties Following Cyclic and Static Straining Under Various Conditions . . . . . . . . . . . . . . . . . . . . . . . . . 16

4 Results of Notch Bend Tests of Locally-Cyclically Strain-Aged Bend Bars _ . . . . . . . 19 


\begin{abstract}
This report describes the results of static and cyclic strain aging effects on the Charpy impact properties of a carbon steel plate (A-212B). From these results it is concluded that:

a. Cyclic strain ranges of 0.5 to $3 \%$ for up to 200 cycles in the temperature range $R T$ to $550^{\circ} \mathrm{F}$ increased the Charpy $50 \%$ FATT by up to $115^{\circ} \mathrm{F}$. The increase in FATT was a direct function of cyclic strain range, number of cycles, and temperature, with maximum embrittlement occurring around $350^{\circ} \mathrm{F}$.

b. Static deformation was considerably less embrittling thän cyclic deformation for equivalent total strain ranges.

c. Notch bend tests of 0.050-in. radius, $20 \%$ deep notch bend specimens with precyclically strain-aged notch regions revealed no significant influence on nominal notch bend strength.
\end{abstract}

\title{
1. INTRODUCTION
}

The effect of static or monotonic deformation at room or moderately elevated temperature to decrease the notch toughness of carbon steel has been well established. ${ }^{1-6}$ It has been observed that the extent of embrittlement as reflected in an increase in the $15 \mathrm{ft}-\mathrm{lb}$ energy or $50 \%$ fibrous transition temperature (FATT) is a function of the amount of cold deformation prior to aging, or for deformation at moderately elevated temperature is a function both of the amount and temperature of deformation. It has also been shown that embrittlement results from reversed cyclic strain at temperature ${ }^{79} ;$ this embrittlement is nominally attributed to a strain-aging mechanism.
It was the purpose of this investigation to systematically determine the influence of both monotonic and cyclic plastic deformation at temperatures in the strain-aging range on the Charpy impact properties of a carbon steel (A-212B). A secondary purpose was to determine the effect of a locally strain-aged region on the notch bend fracture properties of mildly notched bend bars. Determination of specific temperatures for cyclic strain-aging tests was made following static tensile strain-aging experiments over a range of test temperatures.

\section{REVIEW OF PREVIOUS WORK}

It has been observed that the ductile-to-brittle transition temperature is increased following monotonic deform. ation either with or without subsequent low-temperature aging. Additionally, it is a function of the extent of deformation and deformation temperature. W. T. Lankford ${ }^{1}$ in a summary of the effect of prior cold work on the $15 \mathrm{ft}-\mathrm{lb}$ transition temperature of various plain carbon steels observed maximum shifts of about $70^{\circ} \mathrm{F}$ following cold strains up to $10 \%$. The rate of embrittlement with strain varried with materlal; In some cases, near-maximum embrittlement occurred at strains of about $1 \%$. Terazawa and Otari $^{2}$ observed that the $50 \%$ FATT of a $0.14 \%$ C, $0.50 \%$ $\mathrm{Mn}$ steel following both tensile or compressive prestraining at levels to $70 \%$ at temperatures in the range of room temperature (RT) to $1300^{\circ} \mathrm{F}$ increased continuously with strains up to about $50 \%$. For a given strain, the increase in $50 \%$ FATT was maximum after deformation in the range $400-600^{\circ} \mathrm{F}$. An increase in $50 \%$ FATT of $125^{\circ} \mathrm{F}$ was observed after $5 \%$ strain at about $390^{\circ} \mathrm{F}$.
This influence of cold or hot deformation on the strength or load-carrying capacity of notched plates and bend bars has been evaluated. Mylonas ${ }^{3}$ using a simple bend test of unnotched plate of mild steel, has shown that plastic compression or extension performed at temperatures around $500^{\circ} \mathrm{F}$ reduced drastically the ductility in subsequent tension at $-16^{\circ} \mathrm{F}$. Brittle behavior, i.e., fracture at low strains was a function of both deformation temperature and extent Burdekin ${ }^{4}$ in a review of this subject reports results of notched 3-inch-square bend bars bent open and reclosed at RT followed by aging $1 / 2$ hour at $482^{\circ} \mathrm{F}$. A shift of about $195^{\circ} \mathrm{F}$ in the temperature of transition from low to high crack opening displacement was observed for several carbon steels; the effect on notch strength was clearly obvious but appeared to be influenced to a lesser degree. Kiefner and Munse ${ }^{5}$ in tests of notched plates and bend bars of various low carbon steels found that prestraining at temperatures in the range of 400 to $600^{\circ} \mathrm{F}$ renders the material at the root of the notch in bend bars susceptible to 
cracking at loads of about $87 \%$ of the yield load. Also, they observed that brittle fracture can initiate at low applied stresses in the vicinity of welds in mild steel plate; this latter effect implies that regions of the parent plate are severely embrittled by the thermal and strain cycles that accompany welding.

Although there are fewer tests of the influence of cyclic strain on the impact and notch strength properties of carbon steels, effects similar to those described above have been observed following reversed cyclic plastic strain at moderately elevated temperatures. Forrest ${ }^{6}$ found that a $0.17 \% \mathrm{C}$ steel cycled at $350^{\circ} \mathrm{F}$ for $10^{7}$ cycles shifted the Charpy energy curve about $110^{\circ} \mathrm{F}$ to higher temperature. This shift was considerably greater than that observed for an equivalent and higher static strain at the same temperature. Susukida and Ando' for two carbon steels with about $0.18 \% \mathrm{C}$ found an apparent relation between the $15 \mathrm{ft}-\mathrm{lb}$ transition temperature and total plastic strain after cyclic loading at room temperature with no apparent influence of number of cycles. As noted by these authors, the rise in transition temperature was perhaps all or in part associated with an increase in hardness due to hardening during cycling.

A more extensive investigation of the effect of reversed axial strain at $\mathrm{RT}$ and $600^{\circ} \mathrm{F}$ on the Charpy $50 \%$ FATT has been performed by Salkin $^{8}$ for several high manganese, low-alloy carbon steels. Increases in transition temperature of up to about $144^{\circ} \mathrm{F}$ were observed following cycling at $300^{\circ} \mathrm{C}\left(572^{\circ} \mathrm{F}\right)$. Similar cycles at RT produced much less eimbrittlement.

To correlate the influence of strain range and number of cycles, Salkin devised a single parameter derived trom ooncideration of toțl arrumulatart strain, i.e..

$$
\frac{\mathrm{n} \Delta \epsilon_{\mathrm{t}}^{2}}{\epsilon \mathrm{f}^{2}}
$$

where

$$
\begin{aligned}
\Delta \epsilon_{\mathrm{t}}= & \text { total strain range per cycle, } \% \\
\epsilon_{\mathrm{f}}= & \text { true fracture strain, \%, derived from } \\
& \text { tensile reduction in area; and } \\
\mathbf{n}= & \text { number of cycles. }
\end{aligned}
$$

This parameter was then empirically correlated with observed changes in transition temperature, i.e., $50 \%$ FATT. It was observed that the change in transition temperature for several low-alloy steels was greater following deformation In the strain-aging ranye, l.e., $300^{\circ} \mathrm{C}$. This parameter and approach if applicable has merit in that it permits an estimate of the extent of embrittlement for strain ranges and number of cycles other than those tested.

Powers ${ }^{y}$ in fully reversed strain cycling tests of $\mathrm{A} 302$ steel observed an influence of temperature on the stress amplitude to obtain a given strain range, and determined the increase in Charpy impact 50\% FATT after various levels of cyclic strain at $600^{\circ} \mathrm{F}$. A maximum shift of $90^{\circ} \mathrm{F}$ was obtained following 300 cycles at a strain range of $1.3 \%$. This increase was approximately the same magnitude as observed by Salkin for this same steel.

Coffin, ${ }^{10}$ in tests to determine the influence of cyclic strain on fracture properties of low-carbon steels, observed that the ductility transition temperature, i.e., the temperature corresponding to a sharp drop in tensile reduction in area increased about $200^{\circ} \mathrm{F}$ following several cycles at $\pm 1 \%$ strain at $250^{\circ} \mathrm{C}\left(482^{\circ} \mathrm{F}\right)$.

\section{GENERAL TESTING PLAN}

The general testing plan followed is described below.

\subsection{STRAIN AGING IN STATIC TENSILE TESTS}

To determine the general temperature range of maximum static strain-aging effects, and the influence of strain rate on strain aging response, tensile tests were conducted over the range $\mathrm{RT}$ to $600^{\circ} \mathrm{F}$ at various rates. From these tests, the temperature of maximum strain aging as reflected in an increase in strength and/or a decrease in ductility was determined. These tests were conducted on plates in the nnminally stress-relieved condition, i.e., $1050^{\circ} \mathrm{F}$ for $11 / 2$ hours, and for material given a thermal treatment at $1250^{\circ} \mathrm{F}$ for $2-1 / 2$ hours and water quenched. This latter condition was an attempt to simulate possible fast cooling rates associated with welding or other processes resulting in these thermal effects. To determine the influence of static strain-aging on Charpy impact properties, and thus provide a basis for comperison with cyclically strain-aged specimens, a few plate specimens were statically strained to various amounts at $350^{\circ} \mathrm{F}$ and Charpy properties obtained.

\subsection{EMBRITTLEMENT FOLLOWING STRAIN AGING IN CYCLIC TENSIŌN-COMPRESSION TESTS}

After the above tests, 1 -inch-thick plates were cycled over total tension-compression strain ranges of 0.2 to $3.0 \%$ for up to 1,000 cycles at a single slow rate of loading at $350^{\circ} \mathrm{F}$. Also, a few tests were made at temperatures in the range of $R T$ to $550^{\circ} \mathrm{F}$ to determine the influence of test temperature including that associated with reactor operation. Charpy impact properties were determined from these plates to measure the shift in transition temperature relative to the virgin plate material. 


\subsection{LOCALLY INDUCED EMBRITTLEMENT IN NOTCH BEND TESTS}

Since it is likely that strain-aging embrittlement, if it were to occur, would be present as a locally embrittled region, it was believed of value to determine whether low stress fracture of a locally embrittled region could trigger fracture in nominally unaffected base metal. For this purpose, mildly notched bend bars were cyclically deformed at $350^{\circ} \mathrm{F}$ at conditions designed to obtain a shift of $50 \%$ FATT of about $100^{\circ} \mathrm{F}$. Final loading was in compression to avoid inducing compressive residual stresses. These specimens were then tested at temperatures from $-320^{\circ} \mathrm{F}$ to RT to determine possible influence on notch bend strength properties. For comparison with the above results, a single specimen was tested in the non-cyclically strain-aged conditions.

\section{EXPERIMENTAL PROCEDURES}

\subsection{MATERIALS AND TEST SPECIMENS}

The composition and mechanical properties of the experimental material are given in Table 1. These properties as well as the mixed ferrite plus pearlite microstructure shown in Figure 1 are typical for steels of this type and composition.

To establish a reference condition to which the results of various ctrain aging sycles could be compared, all experimental material with the few exceptions noted below were stress-relieved at $1050^{\circ} \mathrm{F}$ for $1-1 / 2$ hours and air cooled. To obtain a uniform and constant metallurgical condition, all cyclic specimens were heated to $350^{\circ} \mathrm{F}$ for 24 hours prior to test. This treatment which resulted in a $50 \%$ FATT of $0^{\circ} \mathrm{F}$ is considered the reference condition for all subsequent tests.

The configurations of the test specimens used are shown in Figures 2 and 3 . These include conventional strip tensile specimens, standard Charpy impact specimens, a notch-bend specimen and a dumbbell-shaped specimen of welded lamellar fabrication. From each of these specimens, a set of Charpy specimens was machined using the orientation shown, i.e., the specimens were transverse with the fracture surface parallel to the direction of rolling, and the length of the specimen perpendicular to the rolling direction.

The notch bend specimen of Figure 3 was employed to determine the effect of local cyclic strain aging on notch bend properties after cycling at $350^{\circ} \mathrm{F}$ to $\pm 0.5 \%$ strain to pre-embrittle the notch. The arrangements used for cycling and testing this specimen are shown in Figure 3. In all cases, the final loading was in compression to avoid inducing favorable compressive residual stresses at the notch.

\subsection{MECHANICAL TEST PROCEDURES}

Standard mechanical test procedures were employed in all tests. Rates of loading for the static tensile tests were $0.001 \mathrm{in.} / \mathrm{in} . / \mathrm{min}, 0.010 \mathrm{in.} / \mathrm{in} . / \mathrm{min}$, and $0.010 \mathrm{in} . / \mathrm{in} . / \mathrm{min}$ plus a 30 minute hold time at $1 \%, 3 \%$, and ultimate tensile strain levels. Since these rates did not exhibit significantly different effects in tensile tests, cyclic strain-aging tests were performed at a rate of $0.002-0.005 \mathrm{in} . / \mathrm{in} . / \mathrm{min}$. Strain ranges for these tests were monitored and controlled over a range of $0.2 \%$ to $3 \%$ using strain gages attached to both sides of the dumbbell specimen. Cycling was performed to obtain a fixed total strain range, irrespective of amplitude. In some cases, the total range was developed by cyclic excursions of equal amplitude in both tension and compression; in other specimens, cycling was to an amount necessary to restore the specimen to its initial length. There was no apparent influence of this variation in cycling path on subsequent embrittlement.

Heating for the strip tensile tests and cyclic strainaging tests was performed in heated insulated cabinets. Heating of notch bend bars and statically loaded plate specimens used resistance-heated electrical tapes. In all cases specimen temperature was monitored with a thermocouple embedded 1/4 inch below the surface of the specimen.

Cycling of notch bend bars to induce a locally strainaged region at the notch was performed in three-point bending over a 7 to 8 -inch span in reversed bending for about 200 cycles. The notch-root strain range of cycling was about $\pm 0.5 \%$ as monitored with a $1 / 32$-inch-long gage length strain gage placed in the notch at the mid-thickness of the specimen. This level of strain in subsequent tests was observed to shift the $50 \%$ FATT by about $100^{\circ} \mathrm{F}$. Thus, the material at the root of the notch can be considered to have a $50 \%$ FATT of about $100^{\circ} \mathrm{F}$ while the FATT of the bulk material is about $-10^{\circ} \mathrm{F}$. Cycling was completed after a compressive cycle to avoid inducing residual compressive stresses at the notch.

To determine the depth and hardness of the strainaged notch root region, microscopic examination of bend bars was performed. This examination revealed no clearly discernible plastic strain zone. Microhardness traverses in the vicinity of the notch indicated a locally-hardened zone about 0.100 -inch deep.

Fracture tests of cyclically strain-aged notch bend bars, and a few virgin specimens for comparison were made in three-point bend-tension over a span of about 7.5 inches. Cooling was performed with either an alcohol-dry ice mixture $\left(-105^{\circ} \mathrm{F}\right)$ or liquid nitrogen $\left(-320^{\circ} \mathrm{F}\right)$. For intermediate temperatures, the bar was cooled to $-320^{\circ} \mathrm{F}$ and allowed to heat to the test temperature. 


\section{TABLE 1}

COMPOSITION AND MECHANICAL PROPERTIES OF

EXPERIMENTAL STEELS

$\begin{array}{cccccccc}\text { Composition } & \mathrm{C} & \mathrm{Mn} & \mathrm{P} & \mathrm{Si} & \mathrm{S} & \mathrm{Cu} & \mathrm{N}_{2} \\ \text { (weight percent) } & 0.24 & 0.74 & 0.015 & 0.24 & 0.031 & 0.23 & 0.007\end{array}$

Grain Size: ASTM No. 6.5

Microstructure - Fine pearlite-ferrite mixture (Figure 1)

Mechanical Properties (Transverse):

\begin{tabular}{|c|c|c|c|c|c|}
\hline $\begin{array}{l}\text { Test } \\
\text { Temp. } \\
\text { ( } \mathrm{F} \text { F) }\end{array}$ & $\begin{array}{l}\text { Ultimate } \\
\text { Strength } \\
\text { (psi) }\end{array}$ & $\begin{array}{c}0.02 \% \\
\text { Yield Strength } \\
\text { (psi) }\end{array}$ & $\begin{array}{c}0.2 \% \\
\text { Yield Strength } \\
\text { (psi) }\end{array}$ & $\begin{array}{c}\text { Red. in } \\
\text { Area (\%) }\end{array}$ & $\begin{array}{l}\text { Elong. in } \\
1 \text { in. }(\%)\end{array}$ \\
\hline Room & 75,883 & 48,875 & 44,666 & 46.1 & 41.5 \\
\hline 125 & 72,500 & 44,800 & 44,700 & - & _- \\
\hline 200 & 72,250 & - & - & - & - \\
\hline 300 & 80,250 & 40,500 & 41,500 & - & - \\
\hline 400 & 83,400 & 38,700 & 39,700 & 28.5 & 20.0 \\
\hline 500 & 85,000 & 30,300 & 36,700 & 31.2 & 31.0 \\
\hline
\end{tabular}

Charpy Impact Properties (Transverse):

As Received - $1050^{\circ} \mathrm{F} \cdot 11 / 2 \mathrm{hrs}$.

As-Received - $1050^{\circ} \mathrm{F} \cdot 1 \mathrm{1} / 2$ hours $+350^{\circ} \mathrm{F}-24 \mathrm{hrs}$.

\begin{tabular}{|c|c|c|c|c|c|}
\hline $\begin{array}{c}\text { Test } \\
\text { Temp. } \\
\text { ("F) }\end{array}$ & $\begin{array}{l}\text { Impact } \\
\text { Energy } \\
\text { (ft-lb) }\end{array}$ & $\begin{array}{l}\text { \% Fibrous } \\
\text { Fracture }\end{array}$ & $\begin{array}{c}\text { Test } \\
\text { Temp. } \\
\left({ }^{\circ} \mathrm{F}\right)\end{array}$ & $\begin{array}{c}\text { Impact } \\
\text { Energy } \\
\text { (ft-lb) }\end{array}$ & $\begin{array}{l}\text { \% Fibrous } \\
\text { Fracture }\end{array}$ \\
\hline 75 & 27.0 & 100 & 75 & 25.5 & 100 \\
\hline 25 & 21.5 & 94 & 0 & 12.5 & 52 \\
\hline 0 & 18.5 & 80 & -25 & 12.0 & 38 \\
\hline-10 & 13.0 & 55 & -50 & 3.5 & 12 \\
\hline-25 & 9.0 & 33 & & & \\
\hline-50 & 4.0 & 11 & & & \\
\hline
\end{tabular}




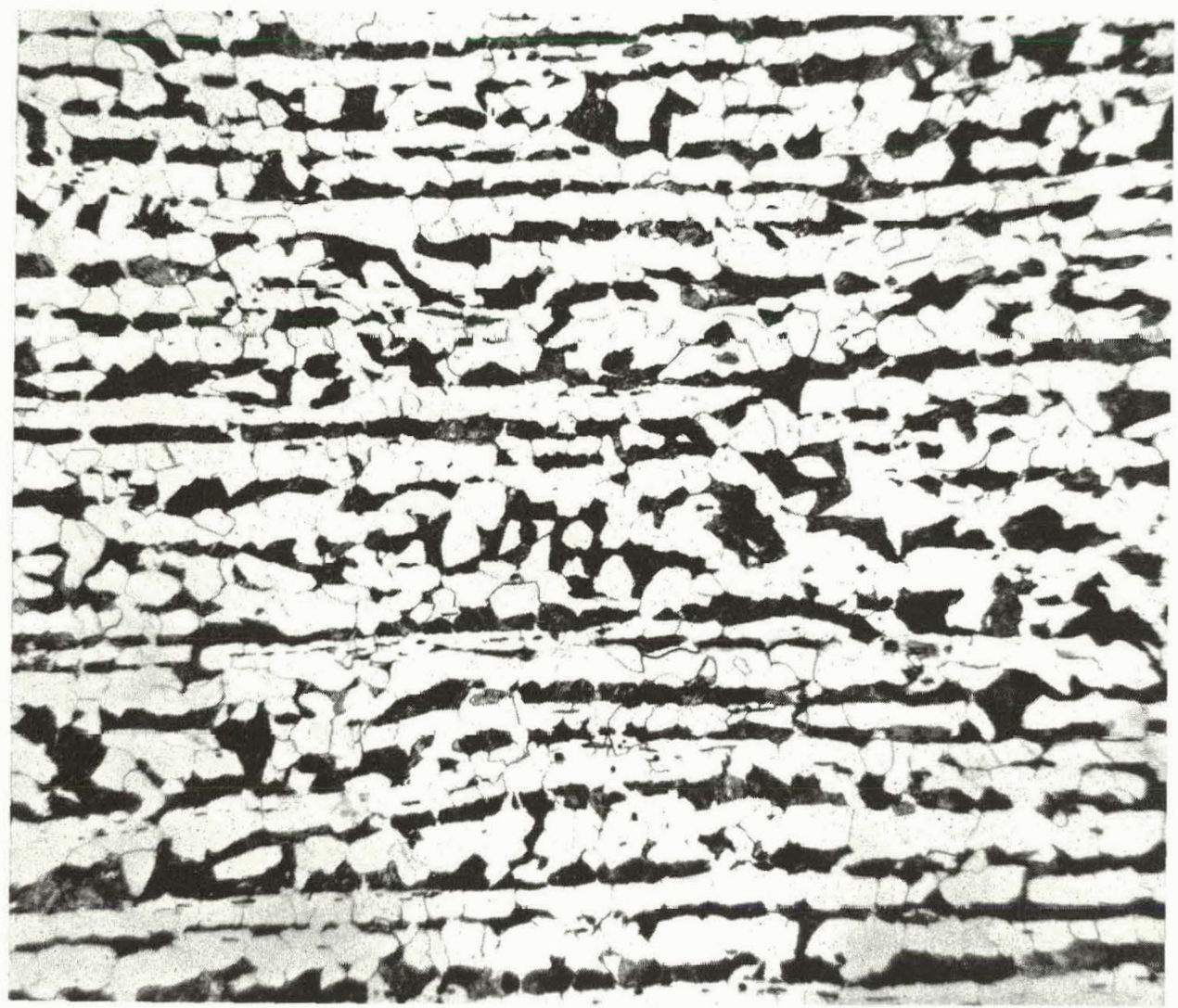

Figure 1. Microstructure of A-212B Carbon Steel Plate

Used for Strain-Aging Experiments. 


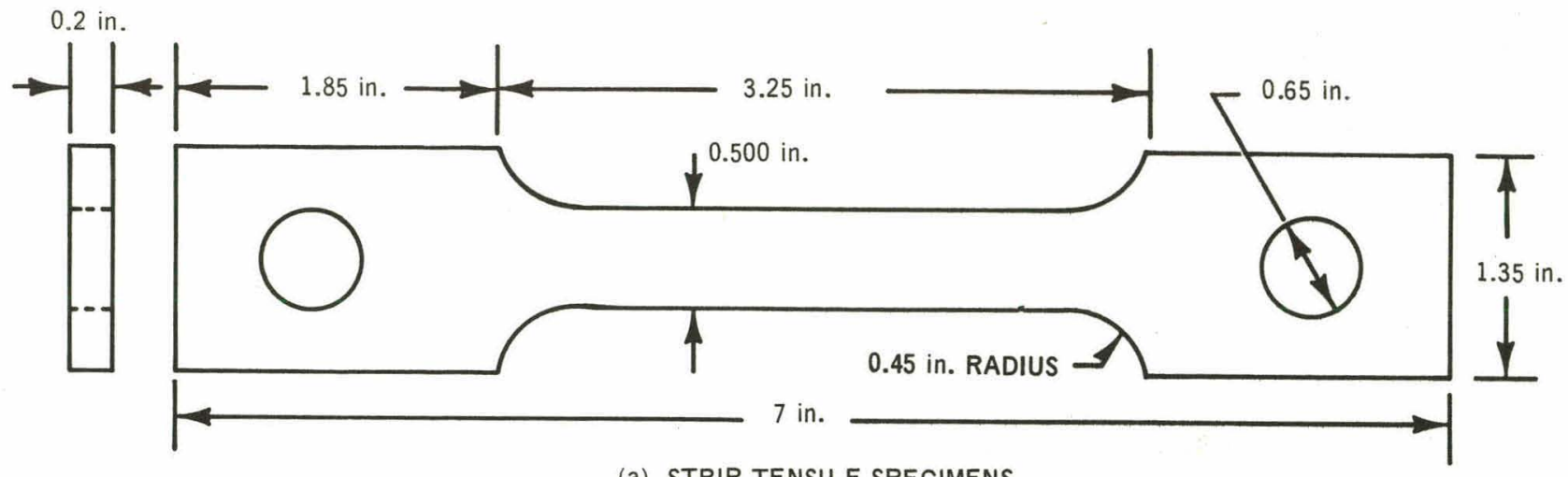

(a) STRIP TENSILE SPECIMENS

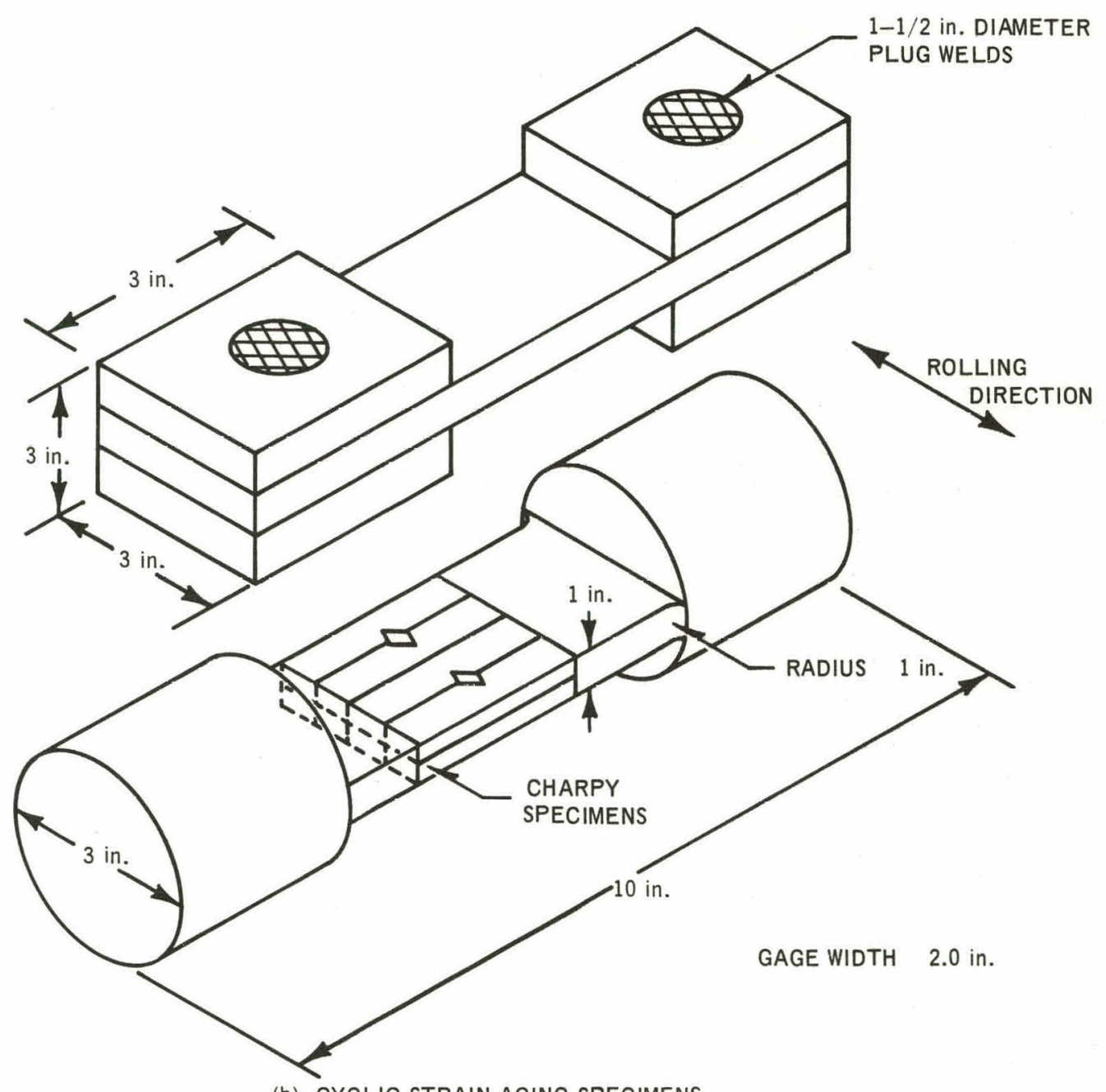

Figure 2 Configuration of Test Specimens 


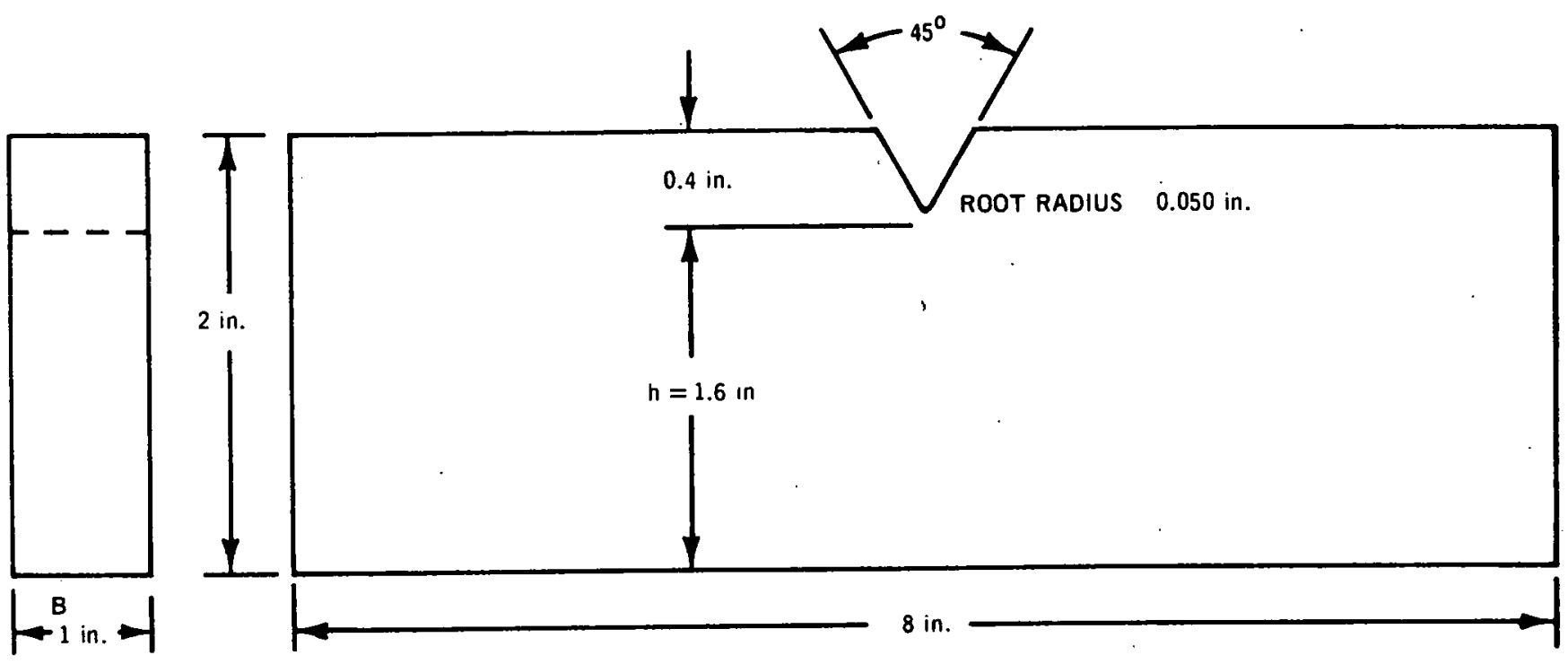

(a) NOTCH BEND TEST SPECIMEN
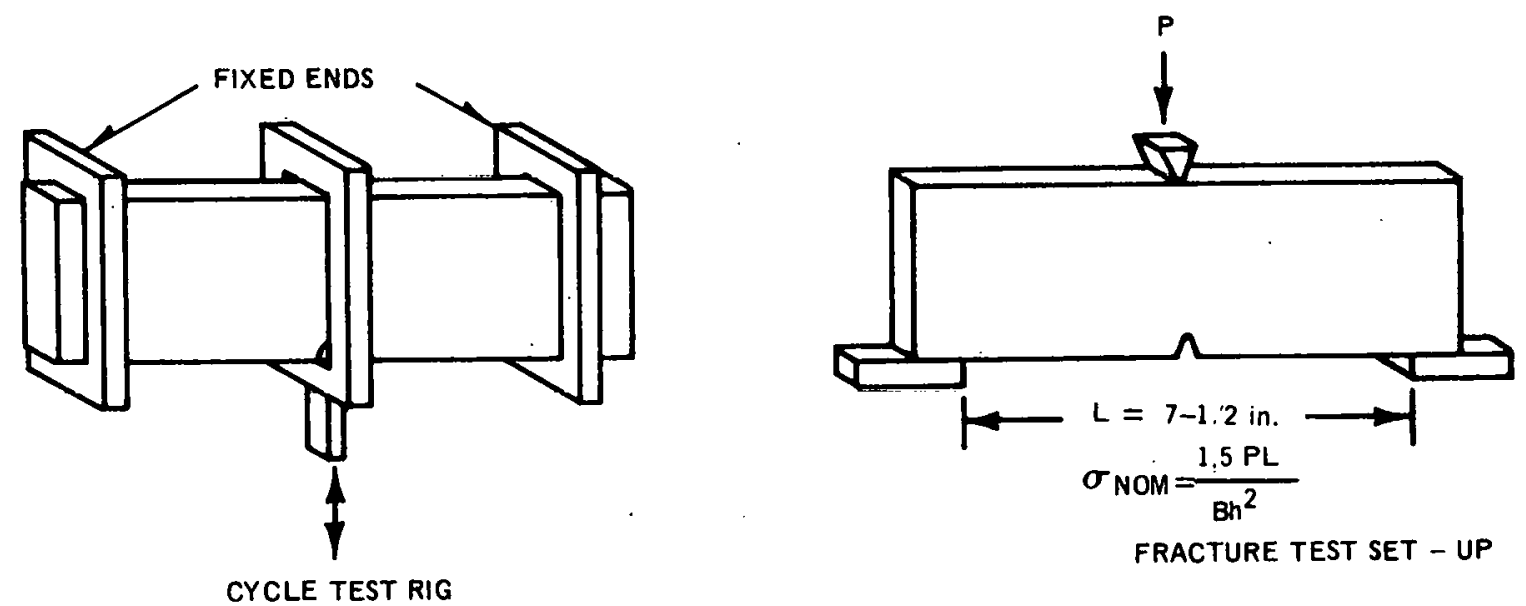

(b) TEST SET-UP

Figure 3 Schematic Features of Test Specimen and Test Set-Up 


\section{EXPERIMENTAL RESULTS}

\subsection{STRAIN-AGING IN STATIC TENSILE LOADING}

The results of tensile tests throughout the strain-aging temperature range are listed in Table 2 and illustrated in Figures 4 and 5 . Figure 4 shows portions of the load. extension curves for the as-received stress-relieved plate, and illustrates the typical serrated or saw-tooth loadextension curve observed for carbon steel in the temperature range of 300 to $400^{\circ} \mathrm{F}$. This phenomenon, associated with discontinuous yielding, is evident at $300^{\circ} \mathrm{F}$ for strains in the yield point region. At $400^{\circ} \mathrm{F}$, serrations do not occur at strains near the yield point, but are evident at higher strains.

The ductility and strength properties are shown in Figure 5. These results indicate that the temperature of minimum ductility coincides with that temperature at which serrations are evident in the load-extension curves. The few tests at lower strain rates, including the influence of a hold-time at various strain levels, indicate a minor effect of this variable, but no appreciable effect on the temperature of maximum embrittlement. Figure 5 also illustrates similar effects for material given a thermal treatment at $1250^{\circ} \mathrm{F}$ for $2-1 / 2$ hours and then water quenched. This treatment generally decreased the absolute level of strength and increased the ductility; however, the tempera. ture of maximum strain-aging was unaffected.

\subsection{STRAIN-AGE EMBRITTLEMENT IN CYCLIC LOADING}

The results of Charpy impact tests following cyclic strain-aging at various temperatures, cycles and strain ranges are listed in Table 3 and shown in Figures 6 through 9. These results include the temperature at which $15 \mathrm{ft}-\mathrm{lb}$ is absorbed, the temperature of $50 \%$ fibrous fracture, i.e.. $50 \%$ FATT, and energy absorbed at $100 \%$ fibrous fracture.

Typical raw results of Charpy impact tests following cyclic strain aging at a given condition are shown in Figure 6. These results indicate the effect of strain-aging to both increase the brittle-to-ductile transition temperature, and to decrease the maximum absorbed energy.

As shown in Figure 7, there is, for a given strain range and cyclic history, an apparent influence of test temperature on shift in 50\% FATT which is qualitatively similar to that observed in results of tensile tests, Figure 4 . The extent of embrittlement increases with increasing test temperature and appears to maximize at 300 to $400^{\circ} \mathrm{F}$; there is the suggestion of lesser embrittlement at $550^{\circ} \mathrm{r}$. The shitt in 15 $\mathrm{ft}-\mathrm{lb}$ transition temperature illustrates similar effects. However, since the maximum energy level is also affected by cyclic strain-aging, a constant energy criterion may not be as unequivocal as that based on fracture appearance.

The influence of cyclic strain range for various numbers of cycles is shown in Figure 8. These results indicate a significant effect of strain range on embrittlement. Also, as shown in Figure 9, there is for a given strain range, an apparent effect of the number of cycles. Over the strain ranges tested, there is evidence that the Charpy transition temperature for a fixed number of cycles increases continually over the strain range examined. However, the influence of the number of cycles in the range 50 to 100 is relatively weak. The maximum shift in $50 \%$ FATT noted was $115^{\circ} \mathrm{F}$ following 151 cycles at $\pm 1.0 \%$.

Figure 8 also shows the shift in transition temperature associated with static deformation at $350^{\circ} \mathrm{F}$. These latter results, though somewhat questionable for the reasons discussed below, indicate a significantly lesser effect of static than cyclic deformation on embrittlement resulting from strain aging.

\subsection{EFFECT OF LOCAL EMBRITTLEMENT IN NOTCH BEND TESTS}

The notch bend fracture properties of this steel over the temperature range of $320^{\circ} \mathrm{F}$ to $\mathrm{RT}$ are shown in Figure 10, and listed in Table 4; typical load-deflection curves are shown in Figure 11. These results indicate within scatter that the nominal net section bend strength calculated from the maximum bending load is essentially high and constant over the range $\mathrm{RT}$ to $-220^{\circ} \mathrm{F}$ with low strength occurring at $.320^{\circ} \mathrm{F}$. Comparison of the two tests at $-150^{\circ} \mathrm{F}$, one of which contained incipient cracks developed during the cyclic straining revealed no appreciable effect of this variable for the conditions tested. Examination of the loaddeflection curves, Figure 11, revealed no evidence of incipient or partial fracture associated with a shallow brittle region. In a single test at room temperature, an attempt to detect acoustical emission, i.e., a "ping", using a contact microphone failed to reveal incipient cracking. Whether incipient cracking occurred at low temperatures with insufficient load-drop to provide an indication on the loaddeflection curve is uncertain.

For comparison purposes and to evaluate the relative effect of local embrittlement on fracture properties, both a fatigue cracked bend bar (notch plus 0.080 -inch-deep fatigue crack, and a virgin bar of mild radius, $0.040 \mathrm{in.} \mathrm{wass}$ tested at $-105^{\circ} \mathrm{F}$. These test results (Figure 10) indicate no significant differences in notch strength, and suggest that the cyclically strain-aged region developed in these tests had no influence on notch bend strength. 


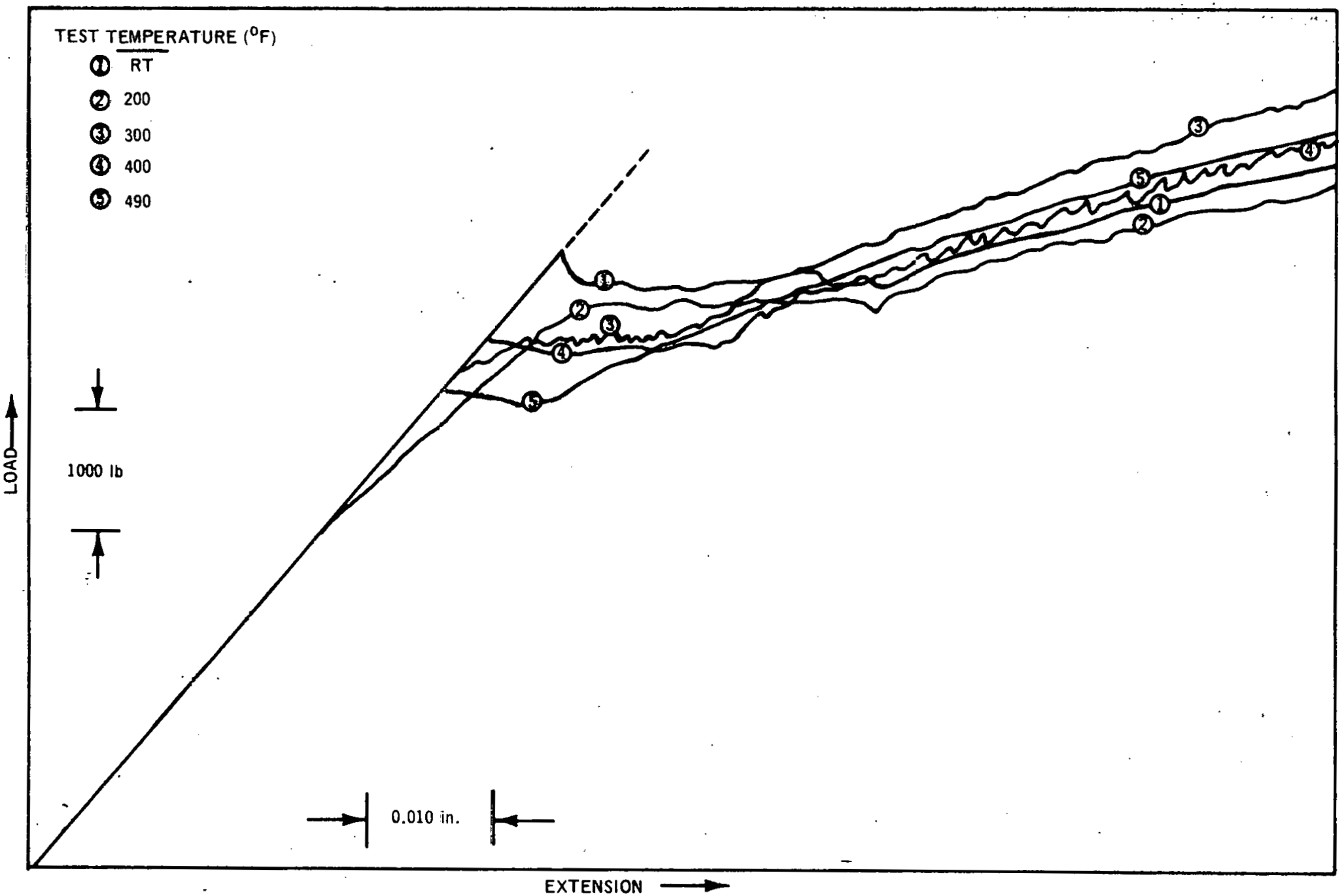

Figure 4. Load-Extensicn Curves for Carbon Steel (A212B) Specimens at $0.010 \mathrm{In} . / \mathrm{In}$./Min Illustrating Serrated or "Saw-Tooth" Curve in Strain-Aging Temperature Range 
TABLE 2

TENSILE PROPERTIES OF CARBON STEEL (A-212B PLATE)

$\begin{array}{ccccc}\text { Spec. } & \text { Test } & \text { Upper Yield } & \text { Lower Yield } & \text { Ultimate } \\ \text { No. } & \text { Temp., }\left(^{\circ} \mathrm{F}\right) & \text { Strength }(\mathrm{ksi}) & \text { Strength (ksi) } & \text { Strength (ksi) }\end{array}$

Condition - As-Received + Stress Relieved $1050^{\circ} \mathrm{F}-0.010 \mathrm{in} . / \mathrm{in} . / \mathrm{min}$

$\begin{array}{rccccc}6 & \text { Room } & 49.8 & 46.7 & 76.1 & 32.0 \\ 14 & 200 & 45.6 & 44.6 & 74.5 & 17.0 \\ 1 & 300 & 44.6 & 43.1 & 85.6 & 14.5 \\ 4 & 400 & 40.3 & 42.3 & 92.1 & 18.0 \\ 15 & 490 & 38.8 & 37.8 & 89.2 & 24.0\end{array}$

Condition - Same as Above - 0.001 in./in./min

$\begin{array}{llllll}5 & 300 & 47.7 & 44.2 & 87.7 & 12.5 \\ 2 & 400 & 43.2 & 42.3 & 94.4 & 24.0\end{array}$

Condition - Same as Above - $0.010 \mathrm{in.} / \mathrm{in} . / \mathrm{min}+30$-min hold @ 1\%, 3\% and strain at maximum load

$\begin{array}{rrrrrr}7 & 300 & 43.5 & 41.5 & 85.0 & 12.5 \\ 16 & 400 & 43.3 & 41.1 & 91.1 & 15.0\end{array}$

Condition $-1250^{\circ} \mathrm{F} \cdot 2.5$ Hours - Water Quenched $\cdot 0.010 \mathrm{in} . / \mathrm{in} . / \mathrm{min}$

$\begin{array}{rccccc}17 & \text { Rōom } & 49.0 & 46.3 & 71.6 & 30.0 \\ 13 & 200 & 44.9 & 43.8 & 71.6 & 21.5 \\ 10 & 300 & 43.9 & 41.4 & 73.2 & 19.0 \\ 3 & 400 & 39.7 & 36.6 & 78.0 & 20.5 \\ 11 & 500 & 30.6 & 30.5 & 74.6 & 24.0\end{array}$




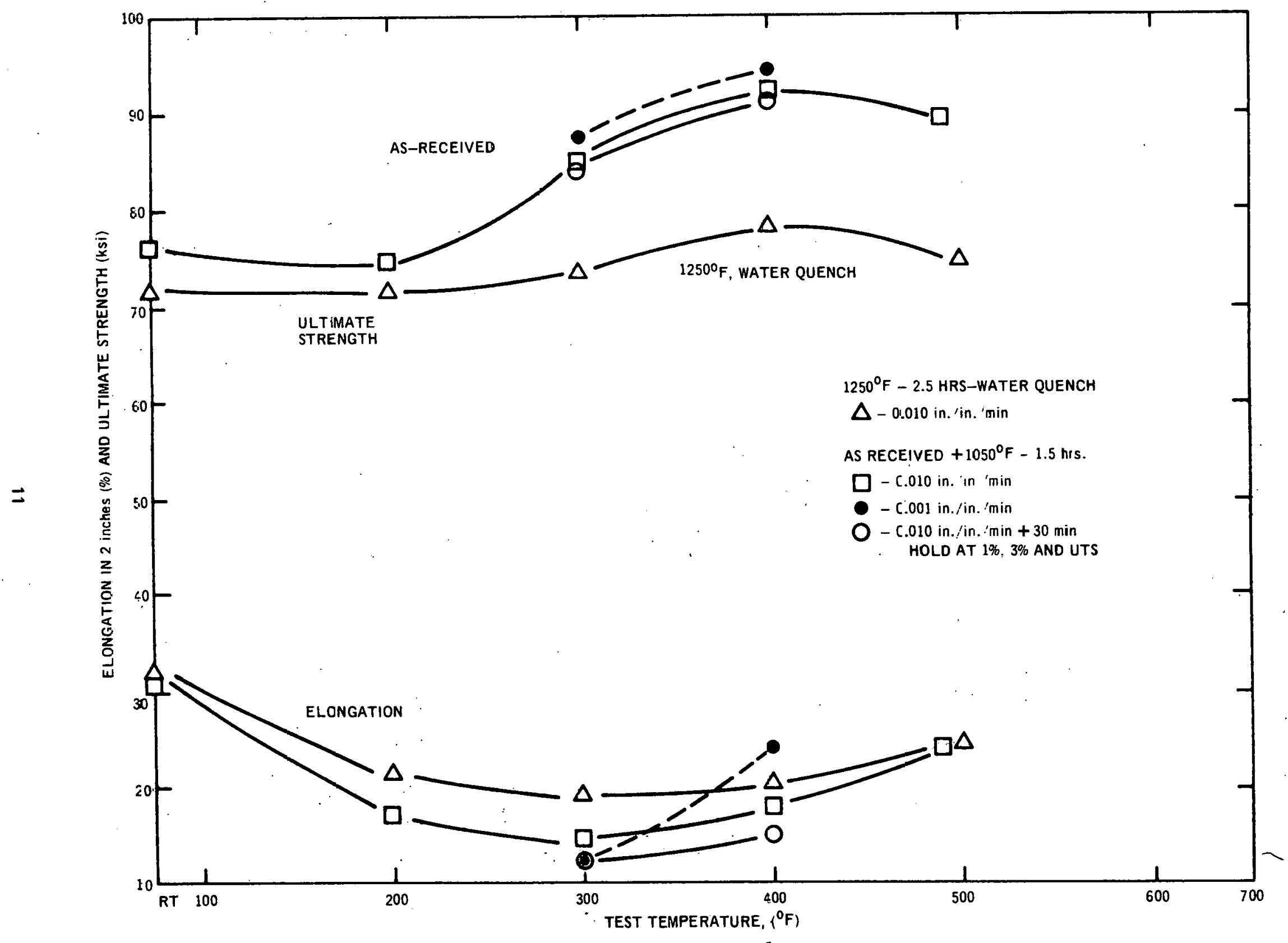

Figure 5. Effect of Test Temperature on Ductility and Strength of A-212B Steel Tested in Tensian at Various Strain Rates 


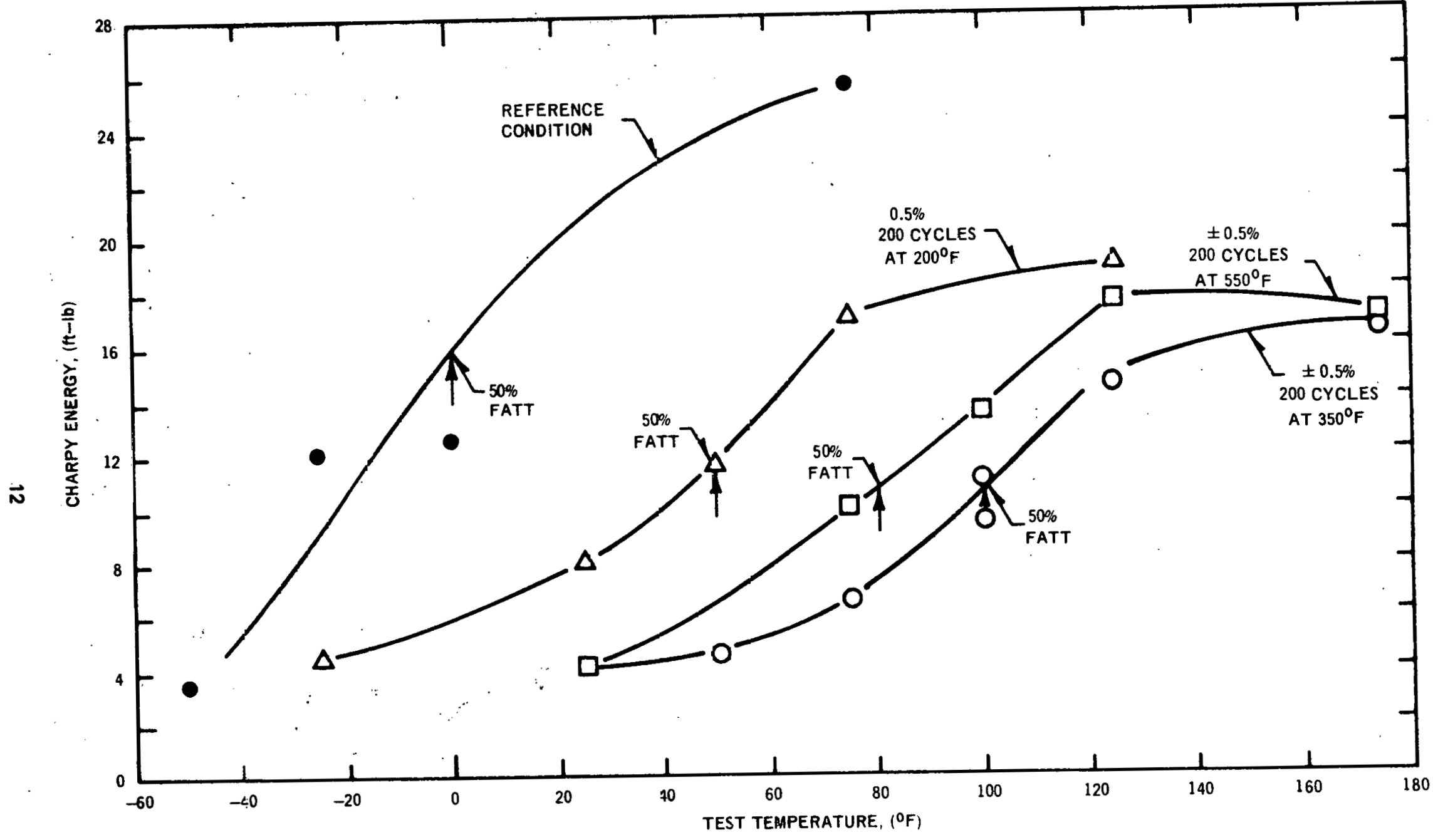

鼻

Figure 5. Typical Charpy Impact Curves 


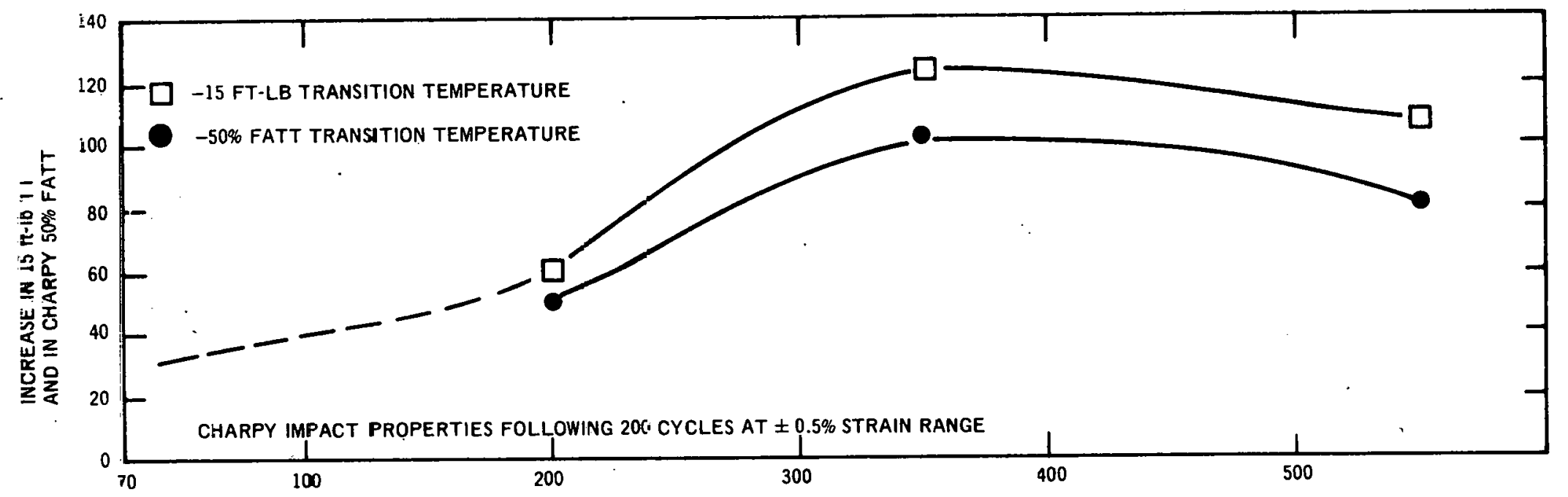

$\dot{\vec{\omega}}$

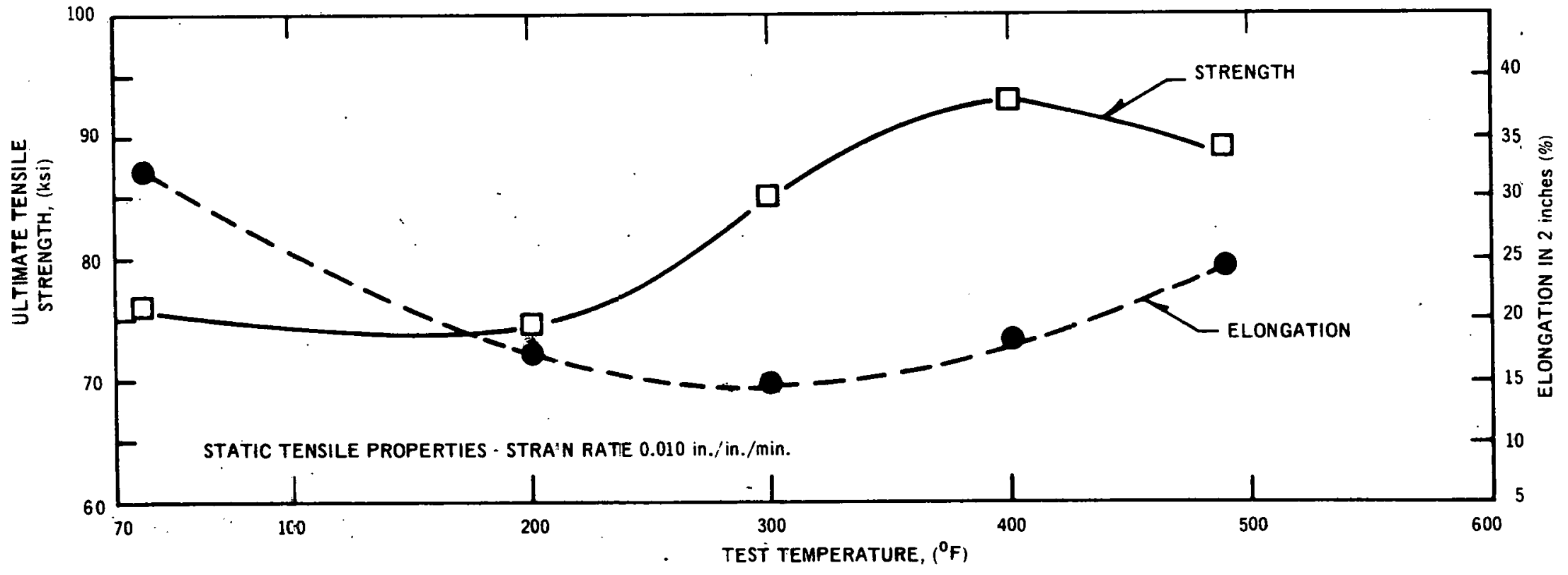

Figure 7. Effect of Test Temperature on Charpy Impact and Static Tensile Properties 


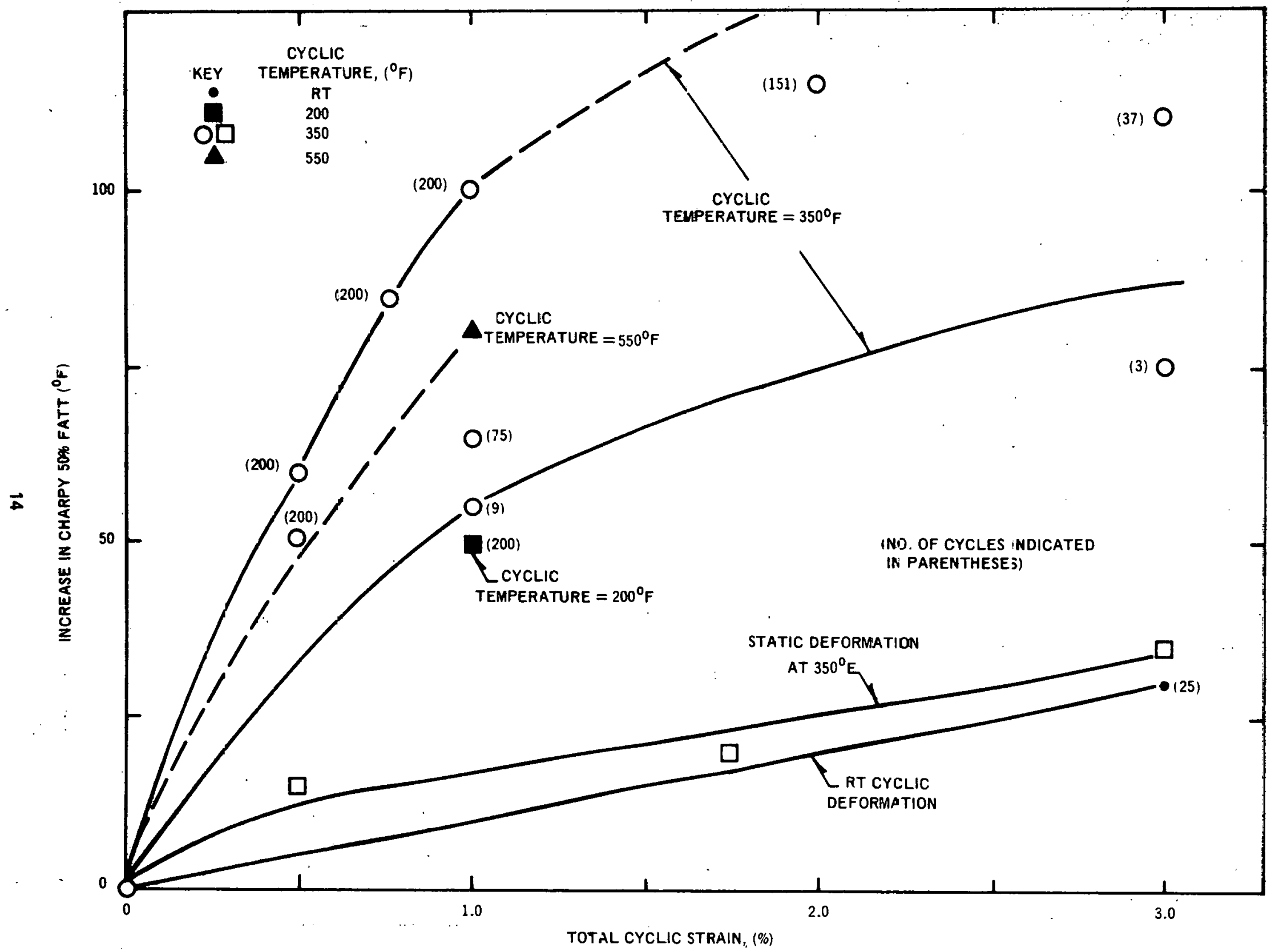

Figure \& Effect of Cyclic Strain at Various Number of Cycles to Shift the Charpy 50\% FATT-Reference Condition 50\% FATT $=0^{\circ} \mathrm{F}$ 


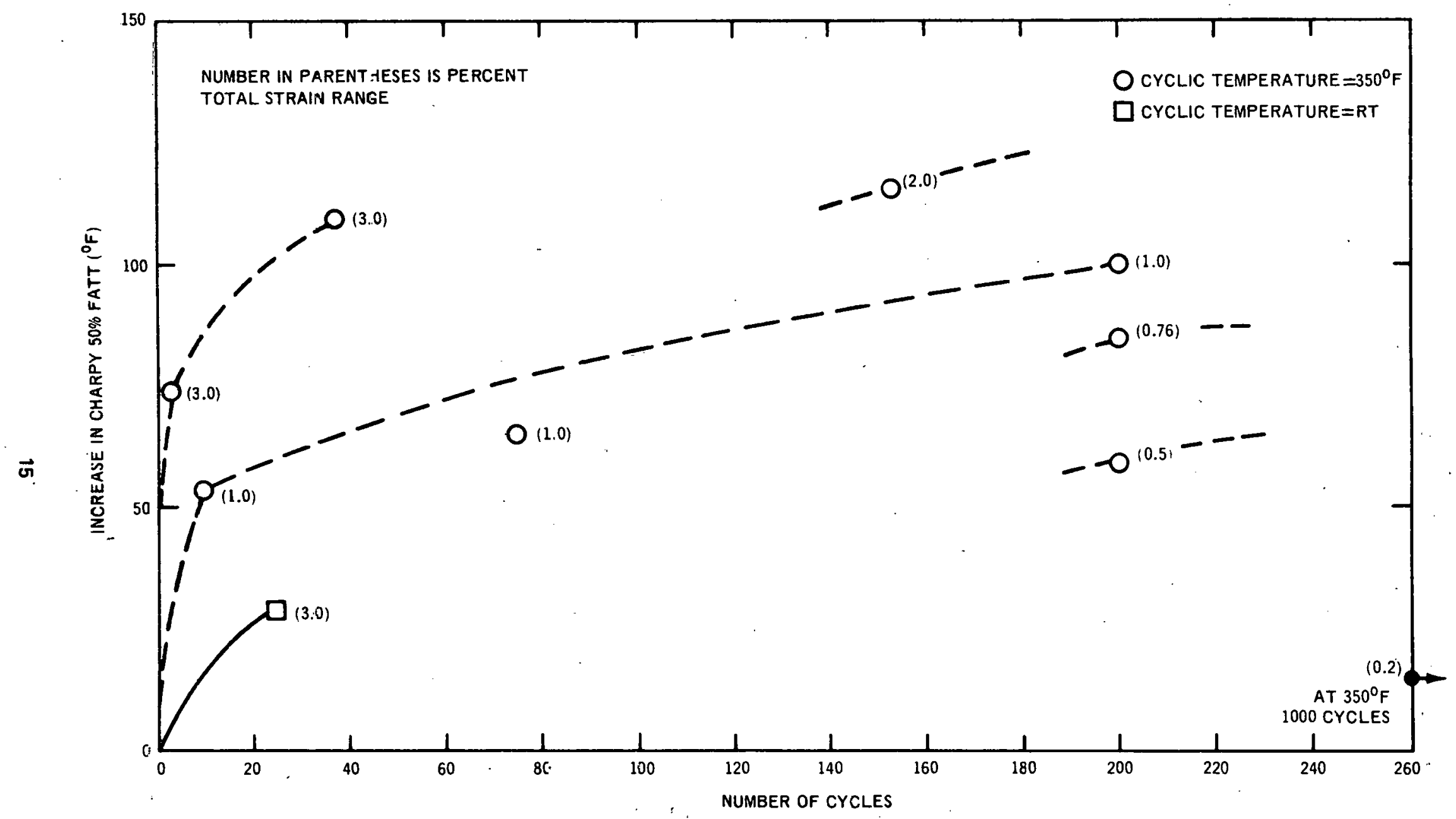


TABLE 3

CHARPY IMPACT PROPERTIES FOLLOWING CYCLIC AND STATIC STRAINING UNDER VARIOUS CONDITIONS

\section{Condition}

1. As-received plus $1050^{\circ} \mathrm{F}-1-1 / 2$ hours plus $350^{\circ} \mathrm{F}-24$ hours

2. $\pm 0.5 \%-20$ cycles plus $\pm 1.0 \%-20$ cycles plus $\pm 1.5 \% \cdot 25$ cycles

3. $\pm 0.5 \%-200$ cycles

4. $\pm 0.10 \%-1000$ cycles

5. $\pm 0.25 \%-200$ cycles $\pm 0.25 \%-200$ cycles

6. $\pm 0.38 \%-200$ cycles

7. $\pm 0.50 \%-9$ cycles

8. $\pm 0.50 \%-75$ cycles

9. $\pm 0.5 \%-200$ cycles

10. $\pm 1.0 \%-151$ cycles

$11 . \therefore \pm 1.5 \%-3$ cycles

12. $+1.5 \%$ - .37 rycies

13. $\pm 0.5 \%-200$ cycles

\section{Charpy $50 \%$ FATT ( ${ }^{\circ} \mathrm{F}$ )}

0

$-5$

0

30

Cycled at $200^{\circ} \mathrm{F}$

50

-15
60
50
85
55
65
100
115
76
110

110

Cycled at $550^{\circ} \mathrm{F}$

80

Statically Deformed @ $350^{\circ} \mathrm{F}$

15. $1.75 \%$

16. $3.00 \%$
Cycled at RT

$+42$

19.0

65

19.0

Cycled at $350^{\circ}$

112

17.5

$15 \mathrm{ft}-1 \mathrm{~b}$

Trans. Temp. ( $\left.{ }^{\circ} \mathrm{F}\right)$

$+5$

$+5$

$+5$

24.5

24.5

Energy

ft-lb

25.5

$-5$

23.0

18.0

22.0

17.0

20.5

36.5

16.5

15.5

13.5

16.0

125

38.0

41.0

39.5 


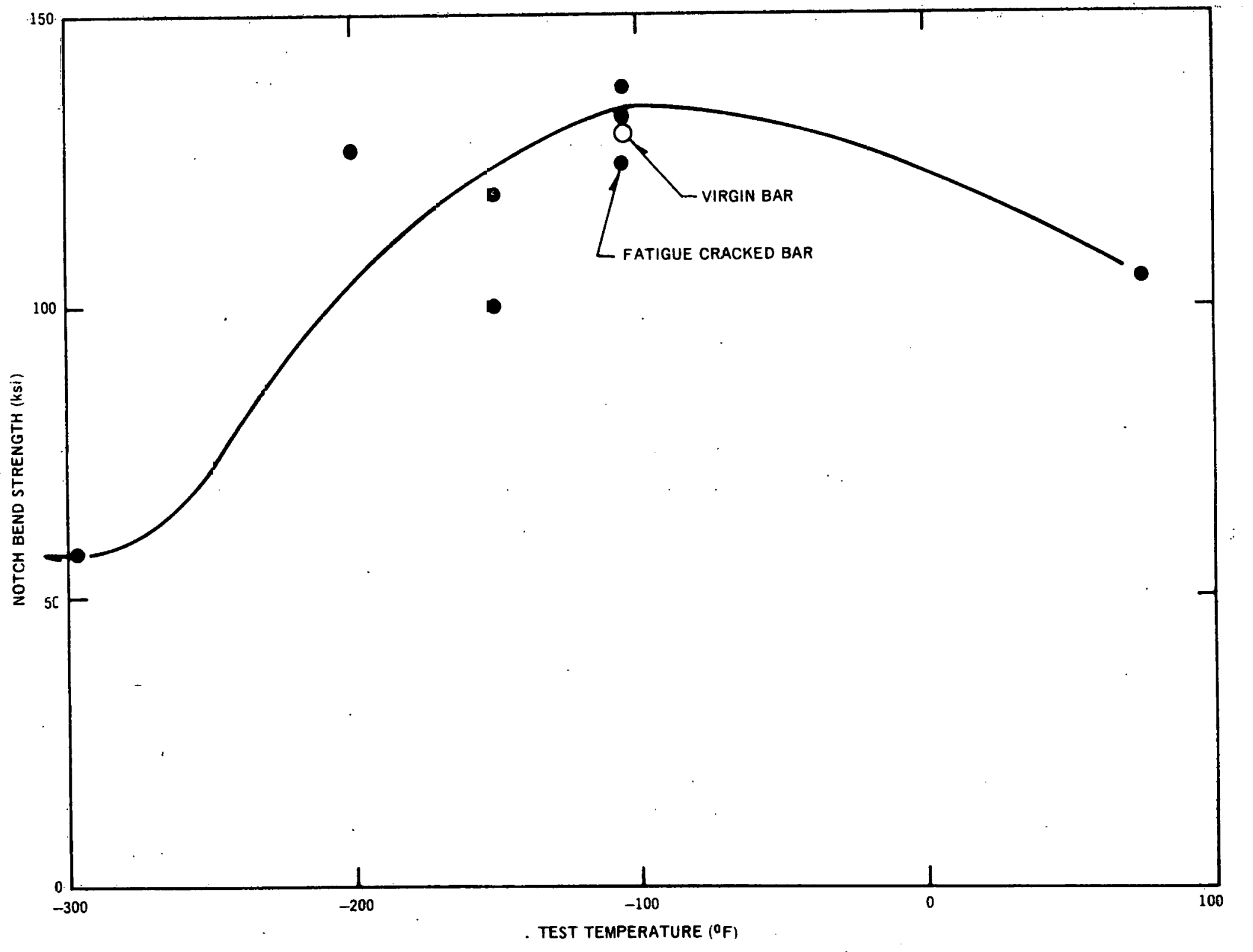

Figure 10. Notch Bend Strength at Fracture as a Function of Temperature for Pre-Cyclically Strain-Aged Specimens 


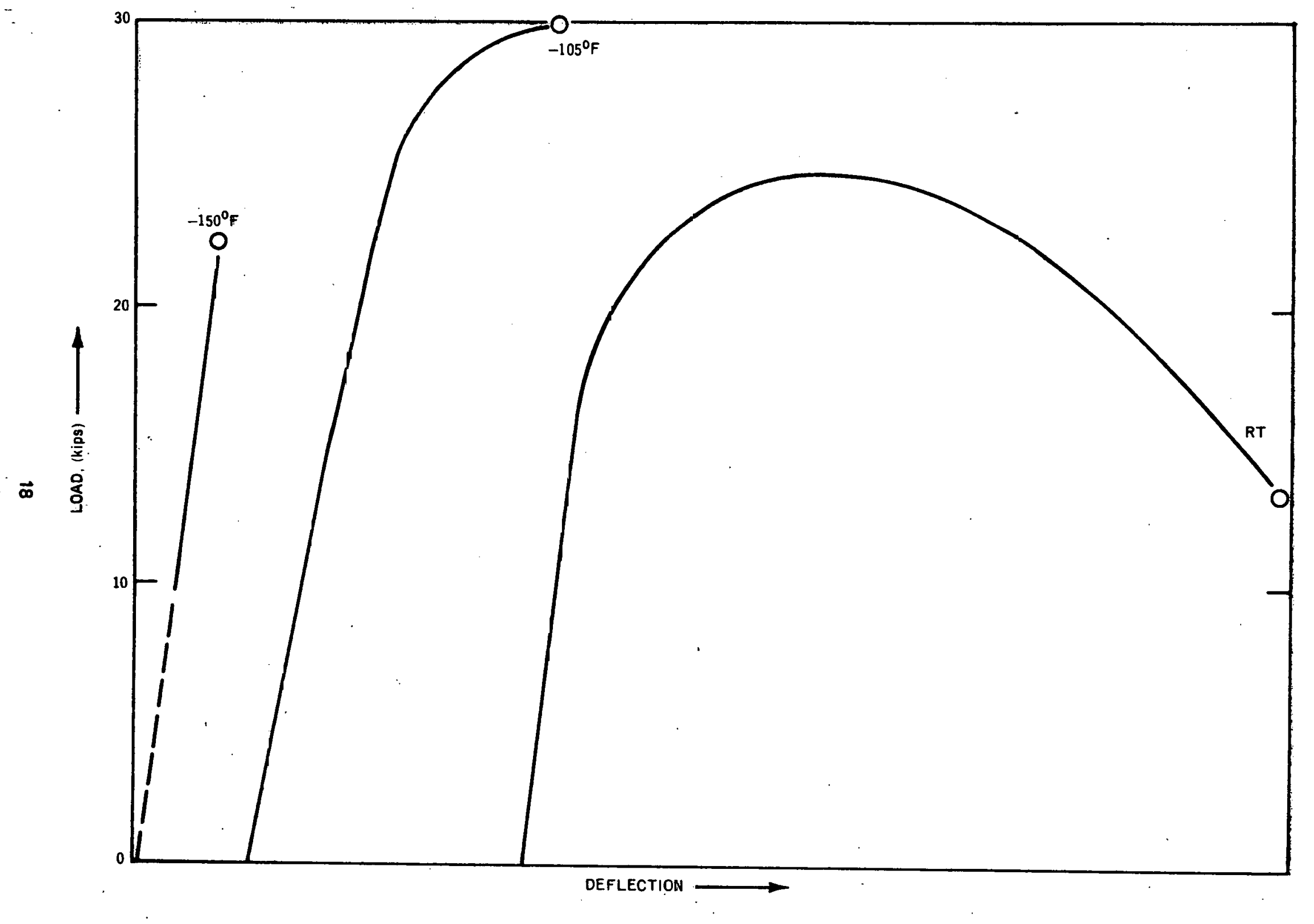

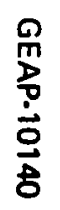

Figure 11. Load-Deflection Curves for Notch Bend Tests 
TABLE 4

\section{RESULTS OF NOTCH BEND TESTS OF LOCALLY-CYCLICALLY} STRAIN-AGED BEND BARS

$\begin{array}{cc}\begin{array}{c}\text { Test } \\ \text { Temp. }\left({ }^{\circ} \mathrm{F}\right)\end{array} & \begin{array}{c}\text { Incipient } \\ \text { Cracks at Notch }\end{array} \\ \text { Room } & \text { No } \\ -105 & \text { Yes }(0.26 \text { in.) } \\ -105 & \text { Yes }(0.07 \text { in.) } \\ -150 & \text { No } \\ -150 & \text { Yes }(0.01-0.015 \text { in.) } \\ -200 & \text { No } \\ -320 & \text { Yes }(0.07-0.08 \text { in.) } \\ -105 & \text { No, as machined } \\ & \text { notch }- \text { not pre- } \\ & \text { strain aged }\end{array}$

\author{
Notch Fracture \\ Strength on Net \\ Section (psi)
}

105,000

138,000

132,500

100,000

119,700

127,600

57,800

131,000
Total Depth of

Fibrous Tear

At Notch (in.)

1.6 (100\% fibrous)

0.32

0

0

0

0

0

0.19

\section{DISCUSSION}

The results of these studies indicate conclusively an embrittling effect of strain aging, the magnitude of which is apparently influenced by test temperature, strain range, and number of cycles. To compare these results with the approach devised by Salkin ${ }^{8}$ calculations were made of the parameter $\left(\mathrm{n} \Delta \epsilon_{\mathrm{t}}{ }^{2}\right) /\left(\epsilon_{\mathrm{f}}{ }^{2}\right)$.

Since these quantities reflect the influence of strain range $\left(\Delta \epsilon_{t}\right)$, number of cycles $(n)$ and, indirectly, test termperature through its effect on tensile reduction in area $\left(\epsilon_{f}\right)$. it has possible usefulness for estimating transition temperatures for those conditions of strain and cyclic history not specifically tested. A correlation, and comparison with the original results by Salkin ${ }^{8}$ for low-alloy steels tested at $300^{\circ} \mathrm{C}\left(572^{\circ} \mathrm{F}\right)$ is shown in Figure 12 . This comparison indicates generally that the rate of emhrittlement associnted with a given strain range-cycle history is considerably greater in Salkin's tests, but that the general parametric concept appears suitable for correlating these variables, at least within the ranges evaluated in these tests.

To determine whether the apparent increase in transition temperature for these tests possibly resulted from simple hardening as a result of cyclic strain history or aging effects, rather than more complex metallurgical phenomena, the Rockwell " $A$ " hardness was determined for several conditions using halves of broken Charpy specimens. An examination of these results shown in Figure 13 revealed a slight but significant trend toward greater hardness with increasing transition temperature.

An evaluation of some of the tensile specimens by electron microscopy is given in Appendix $A$.

As noted above, some qualifications are to be noted with regard to the Charpy impact test results following sta. tic deformation at $350^{\circ} \mathrm{F}$. Since these specimens were possibly erroneously machined from a second plate of A-212B, and were tested in the as-received condition without stress relief, or a pretest age, there is some question regarding the validity of comparing the two sets of results. Tests to evaluate the influence of the variables of stress relief at $1050^{\circ} \mathrm{F}$ for $1-1 / 2$ hours, or a pretest at $350^{\circ} \mathrm{F}$ for 24 hours indicates that these variables could increase the $50 \%$ FATT by perhaps $10^{\circ} \mathrm{F}$; this is within the data scatter band of the Charpy impact test, and presumably has little influence. The possibility that this plate represents a second plate of unknown virgin properties is relevant, and this possibility is strengthened by the rather high but not unusual maximum energy values for the static tests.

Comparison of the notch bend properties of this study with those obtained by Burdekin ${ }^{4}$ suggest generally. similar results for the influence of temperature on notch strength; however, in that case, low stress fracture with subsequent arrest was noted in several instances. Of most significance in these prior tests was the apparent and strong effect of aging on the crack-opening-displacement (COD), or notch strain prior to fracture. As noted previously, the transition from low-to-high COD increased about $195^{\circ} \mathrm{F}$ for the cold-bent and aged specimens relative to those stressrelieved to remove these effects. Since the notch opening in these tests was not measured it is not possible to compare Burdekin's and these results directly. However, Burdekin's work, particularly the incidence of low stress crack arrest suggests that the few tests made in this study may not be conclusively and generally definitive. 


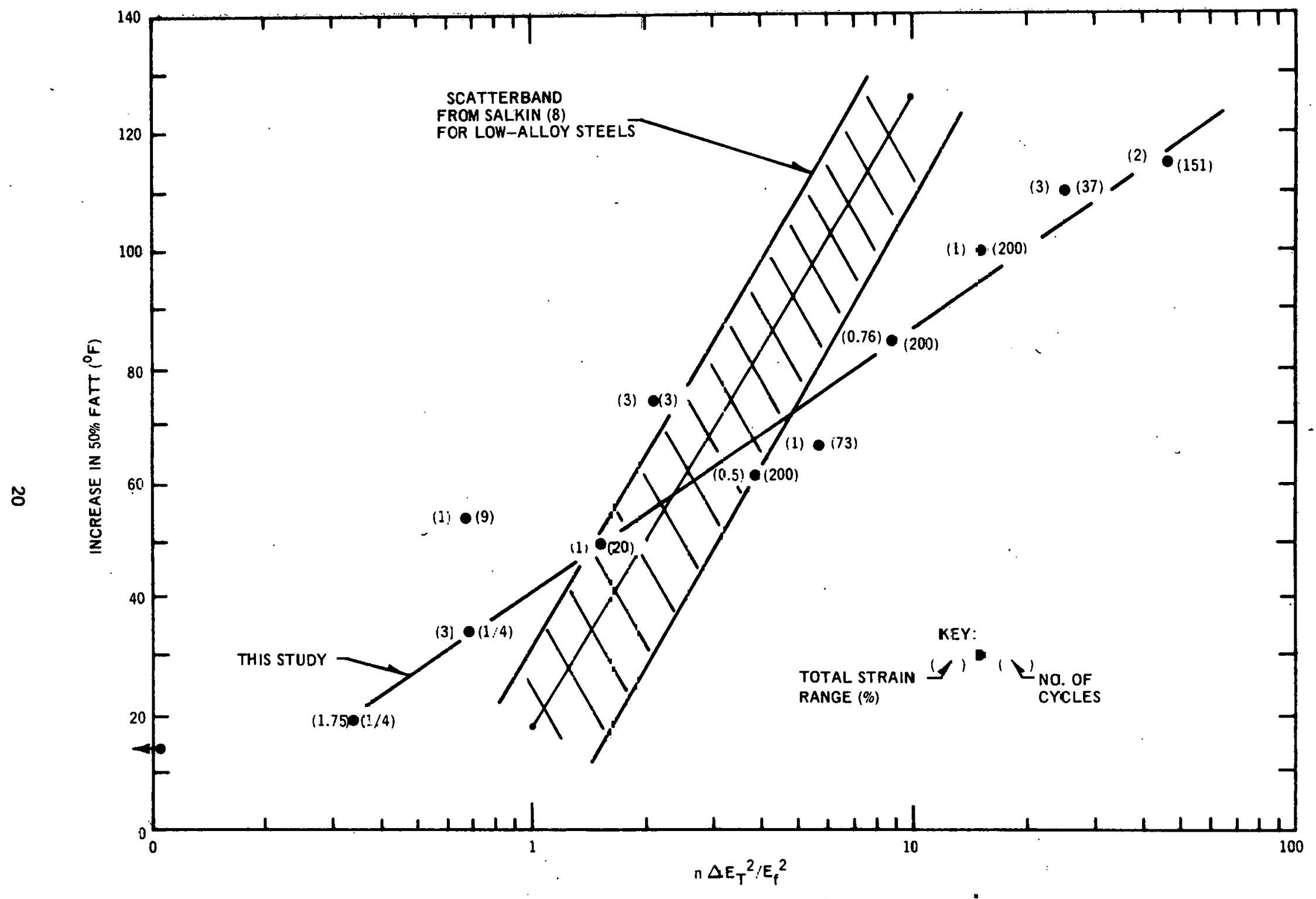

Figure 12 Correlation of Increase in 50\% FATT with Cyclic Strain History Parameter 


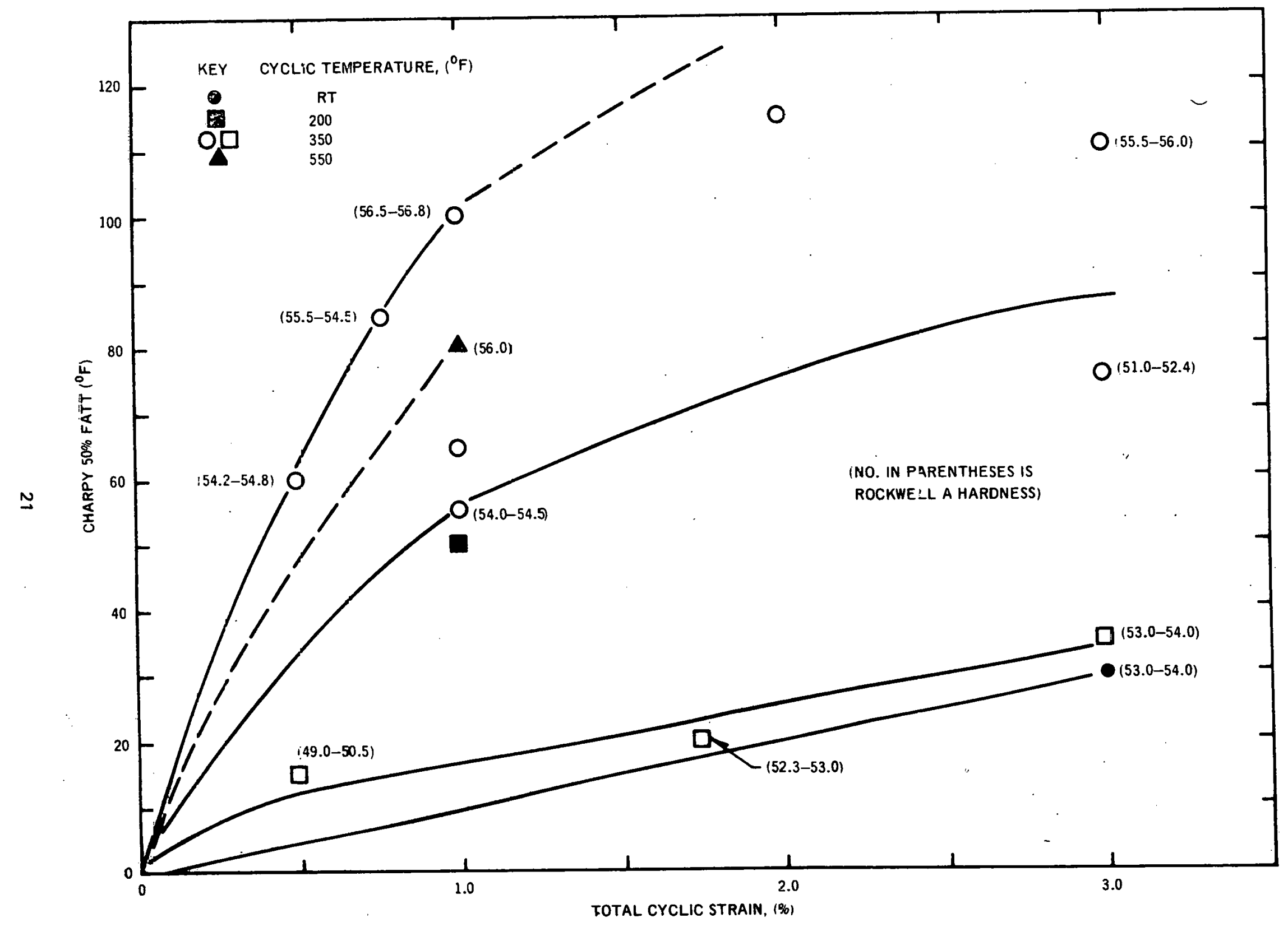

Figure 13. Correlation of Charpy 50\% FATT with Total Cyclic Strain Range Illustrating Hardness Changes - See Figure 8 


\section{SUMMARY AND CONCLUSIONS}

The influence of both static and cyclic strain aging on the Charpy impact properties of a $0.24 \%$ carbon steel (A-212B) was determined. It was observed that both static strain aging in tensile specimens as reflected in a minimum in ductility or a maximum in strength occurs in the temperature range 300 to $400^{\circ} \mathrm{F}$ for this steel. Also, it appears that this temperature corresponds to that at which a maximum is observed in the Charpy $50 \%$ FATT following a given cyclic strain aging condition.

Examination of the influence of strain range and number of cycles indicates both to be important variables. $A$ maximum shift of about $115^{\circ} \mathrm{F}$ in $50 \%$ FATT was observed after 151 cycles at $\pm 1.0 \%$ strain at $350^{\circ} \mathrm{F}$. At $550^{\circ} \mathrm{F}$, less change occurs in the shift of the Charpy transition temperature, i.e., $\pm 0.5 \%$ for 200 cycles led to a. shift of $80^{\circ} \mathrm{F}$ whereas for equivalent straining at $350^{\circ} \mathrm{F}$ the change in $50 \%$ FATT was $100^{\circ} \mathrm{F}$.

Examination of the influence of a locally cyclically strain-aged embrittled region in a mildly notched bend bar indicates no apparent influence on notch bend strength at fracture for the range of conditions tested. This phenomenon which is contrary to that observed previously by others may result from a lesser extent of embrittlement in these specimens, and should not be considered as a general effect.

\section{REFERENCES}

1. Lankford, W. T., "Effect of Cold Work on the Mechanical Properties of Pressure Vessel Steels," Welding Journal Research Supplement, April 1956, p. $195 \mathrm{sf}$.

2. Terazawa, K., and Otari, M., "Effect of High Temperature Prestraining on Notch Toughness of Steel," Int. Institute of Welding, Doc. No. IX-286-61, 1961.

3. Mylonas, C., and Rackey, K. C., "Exhaustion of Ductility by Hot Straining-An Explanation of Fracture Initiation Close to Welds," Welding Jnl. Res. Suppl., 40, July 1961, p. 306s.

4. Burdekin, F. M., "The Initiation of Brittle Fracture in Structural Steels," Welding Engineer, October 1967.

5. Kiefner, J. F., and Munse, W. H., "Influence of Thermal and Strain Cycling on Fracture Susceptibility of Mild Steel," $U$. of Illinois Report, February 1967.
6. Forrest, P. G., "Effect of Fatigue Stressing on the Susceptibility of Steel to Brittle Fracture," The Engineer, July 1963.

7. Susukida, H., and Ando, T., "Effect of Low Cycle Fatigue on the Brittle Fracture of Steel," The Ninth Japan Congress on Testing Materials, March 1966.

8. Salkin, R. V.. The Effect of Low Cycle Fatigue and Neutron Irradiation on the Mechanical Properties of Low Alloyed Stee/s, Presented at 13th Annual Meeting of American Nuclear Society, San Diego, California, June 11, 1967.

9. Powers, A. E., The Effect of Plastic Strain Cycling on the Mechanical Properties of Type A302B Steel, General Electric Company, KAPL Materials Engineering Memorandum No. 234, June 1969.

10. Coffin, L. F. Jr., "The Effect of Quench-Aging and Cyclic Strain-Aging on Low Carbon Steel," Jnl. of Basic Eng., Trarıs. ASME, 87, June 1965, p. 351.

\section{ACKNOWLEDGMENT}

The advice and counsel of Dr. L. F. Coffin in the problem recognition and in the experimental design of the cyclic strain aging program is gratefully acknowledged. 


\section{APPENDIX A \\ ELECTRON MICROSCOPY OF STRAIN-AGED PLAIN CARBON STEEL}

To supplement the study of the effect of static and cyclic strain aging on the Charpy impact properties of a carbon steel, several of the specimens were examined by electron microscopy. The objective of this aspect of the work was to determine whether the extent of strain aging and the associated increase in transition temperature could be correlated with concomitant structural changes. Although it is believed that maximum effects are related to rather subtle structural modifications, precipitates have been reported in some cases following prolonged strain aging. It has also been demonstrated that dislocation density is dependent on the extent of strain aging occurring during a test. ${ }^{1}$ Accordingly, specimens have been examined for evidence of precipitation and changes in dislocation density and dislocation configuration.

\section{A.1 RESULTS}

Relief replicas were prepared from tensile specimens deformed to failure at RT, $300^{\circ} \mathrm{F}$, and $490^{\circ} \mathrm{F}$. Areas close to the fracture and in the undeformed grips were examined. No evidence of precipitation was detected and there were no significant structural changes as a result of the strain and temperature exposure. Figure A-1 shows examples of the structure close to the fracture for the three test temperatures. The micrographs show regions of both ferrite and pearlite.

$\begin{array}{cc}\text { Temperature }\left({ }^{\circ} \mathrm{F}\right) & \text { Strain Range (\%) } \\ \text { Room } & 0.5 \\ 350 & 1.5 \\ 350 & 0.5 \\ 350 & 0.38 \\ 490 & 0.5\end{array}$

Figure A-3 shows the dislocation structure and illus. trates rather well defined cells approximately $0.5 \mu \mathrm{m}$ diameter in all cases for the three specimens cycled at $350^{\circ} \mathrm{F}$. No significant structural differences were observed for the different cyclic exposures. The structure in the specimen cycled at RT is shown in Figure A-4. In general, the cells appeared to be at an earlier stage of formation with considerable tangling within them. After cycling at $490^{\circ} \mathrm{F}$, the dislocations have formed a very distinctive elongated cellular structure shown in Figure A-5. The dark contrast at the cell walls indicates a very high dislocation density and the straight dislocation segments within the cells demonstrate continued accumulation of plastic strain.
Examination of thin foils prepared by electrolytic polishing of transverse sections cut from close to the fracture of these same specimens, where the local strains were between 10 and $20 \%$, revealed some dislocation tangling and the beginning of cell formation. Figure A-2 illustrates the type of dislocation structure obtained at the three test temperatures. In general, after deformation at RT, the dislocations tended to be relatively straight. A number of fairly well defined sub-boundaries consisting of dislocation nets were observed [Figure A-2 (A)]. At the higher test temperatures [Figure $A-2(B)$ and $(C)$ ] far more dislocation tangling was apparent and small areas of fairly dense dislocation structures indicated an early stage of cell formation. No significant difference was observed in the specimens deformed at $300^{\circ} \mathrm{F}$ and $490^{\circ} \mathrm{F}$. These observations are rather similar to previous reports of the effect of deformation temperature on the dislocation structure of $\alpha$-iron ${ }^{24}$ where the tendency to form cells increased with increasing strain and increasing temperature up to about $500^{\circ} \mathrm{F}$.

The maximum increase in transition temperature for this material was obtained after cycling at $350^{\circ} \mathrm{F}$. Thin foils were therefore prepared from parallel to the initial rolling plane for several specimens cycled at this temperature. In addition, one foil was examined for each of the other test temperatures. The cycling conditions and the measured increases in 50\% FATT for these specimens are described below:

$\begin{array}{rr}\text { Cycles } & \Delta \text { FATT }\left(^{\circ} \mathrm{F}\right) \\ 20 & 30 \\ 37 & 110 \\ 200 & 100 \\ 200 & 85 \\ 200 & 80\end{array}$

\section{A.2 DISCUSSION}

The extent and morphology of dislocation cell formation appears to depend on the temperature and deformation mode. However, with the limited number of observations made, it is not possible to relate the structure directly to the measured increase in transition temperature. Although the specimens tested at $350^{\circ} \mathrm{F}$ have similar transition temperatures and similar cellular development, the specimen tested at $490^{\circ} \mathrm{F}$ would clearly not fit into a general pattern relating structure and FATT. It is possible that the type of dislocation configuration is mainly controlled by the crystal structure and the deformation conditions, rather than resulting from dislocation-interstitial reaction. 
For example, decarburizing has been shown not to significantly affect the dislocation structure of $\alpha$-iron deformed at various temperatures in tension. ${ }^{3}$ It seems probable, therefore, that the measured FATT cannot be related uniquely to the dislocation structure. Among other factors, the den- sity of mobile dislocations, which cannot be determined from an electron micrograph and will depend on the extent of dislocation locking, must be important in determining the response to any subsequent mechanical property test.

\section{REFERENCES}

1. Baird, J. D., and Mackenzie, C. R., J.I.S.I., 202 , (1964), 427.

2. Carrington, W., Hale, K. F., and McLean, D., Proc. Roy. Soc., 259, (1960), 203.
3. Brandon, D. G., and Nutting, J., J.I.S.I., 190, (1960), 160.

4. Keh, A. S., and Weissman, S., "Electron Microscopy and Strength of Crystals," Interscience, New York, (1963), 231. 
(A)

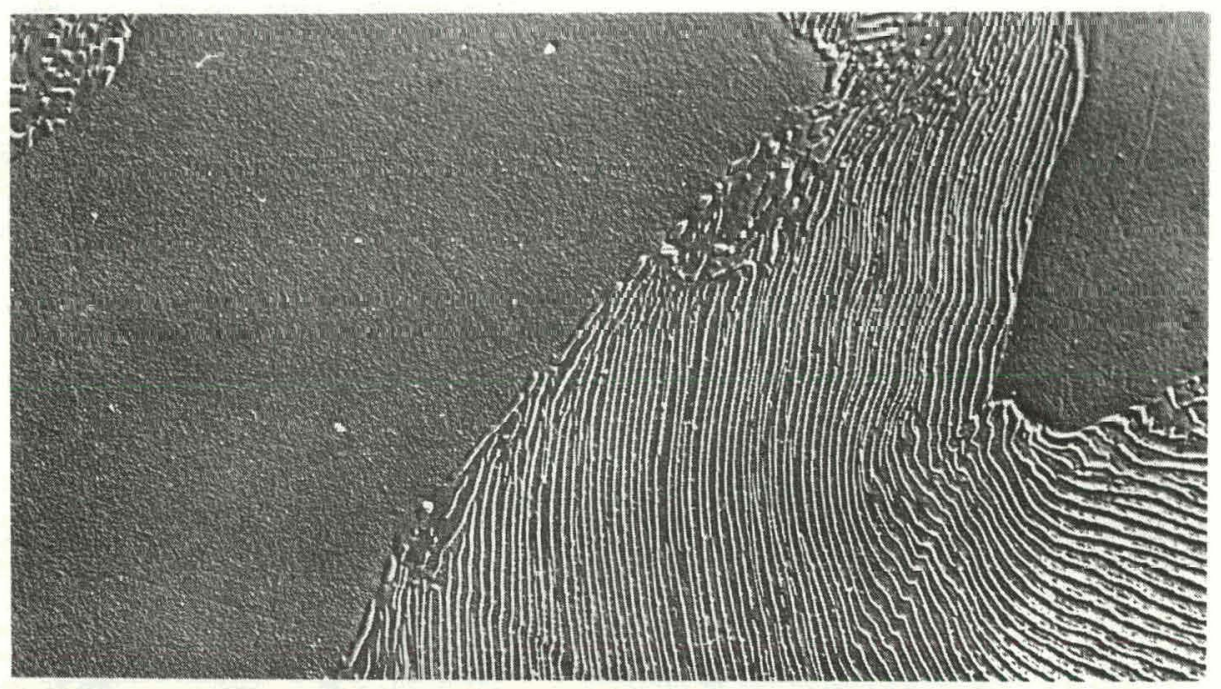

(R)

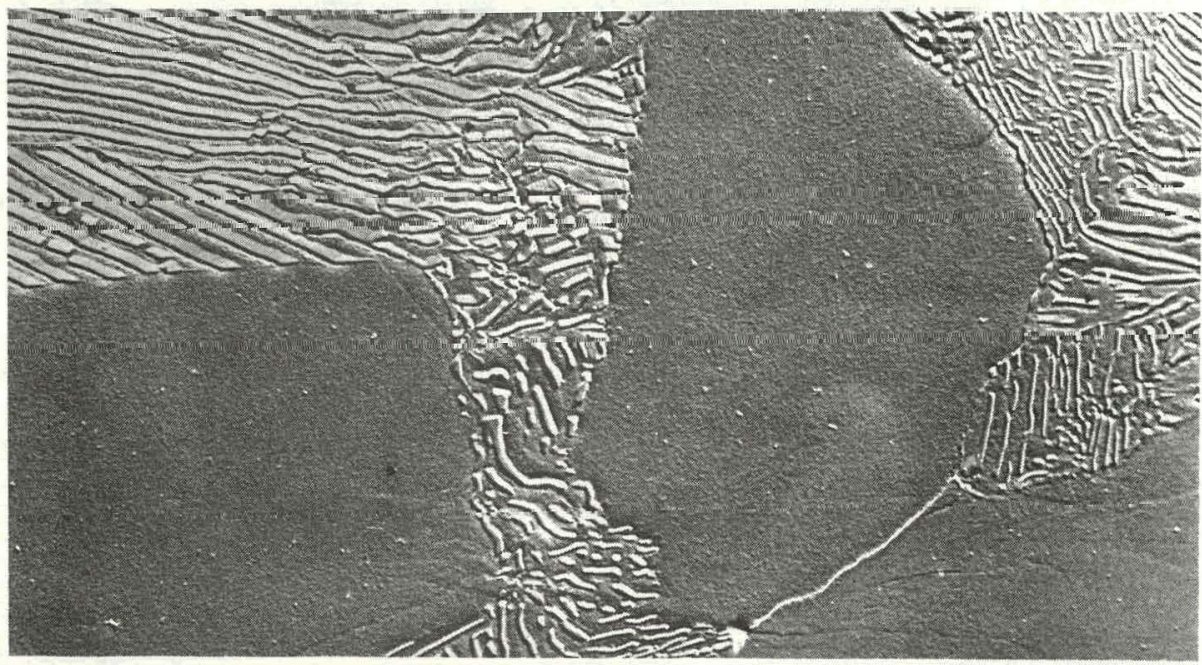

(C)

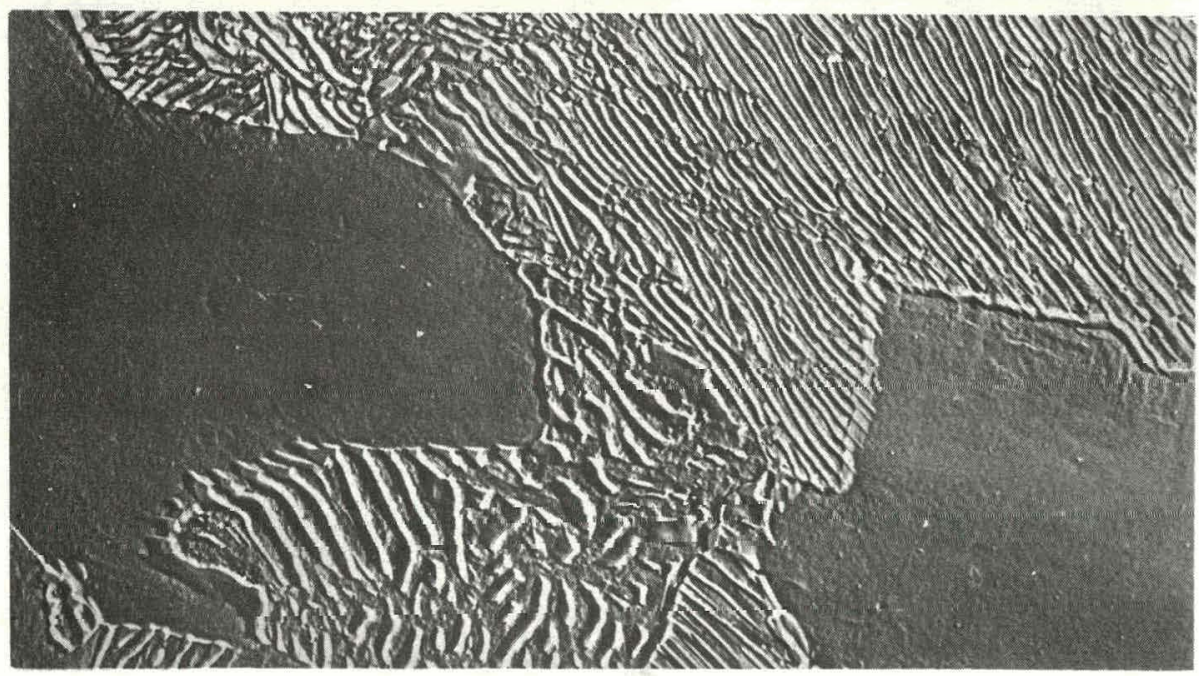

Figure A-1. Relief Replicas Taken From Close to Fracture of Specimens Deformed in Tension at A) $R T$ B) $300^{\circ} \mathrm{F}$ and C) $490^{\circ} \mathrm{F}$ 
$\left(A^{\prime}\right.$

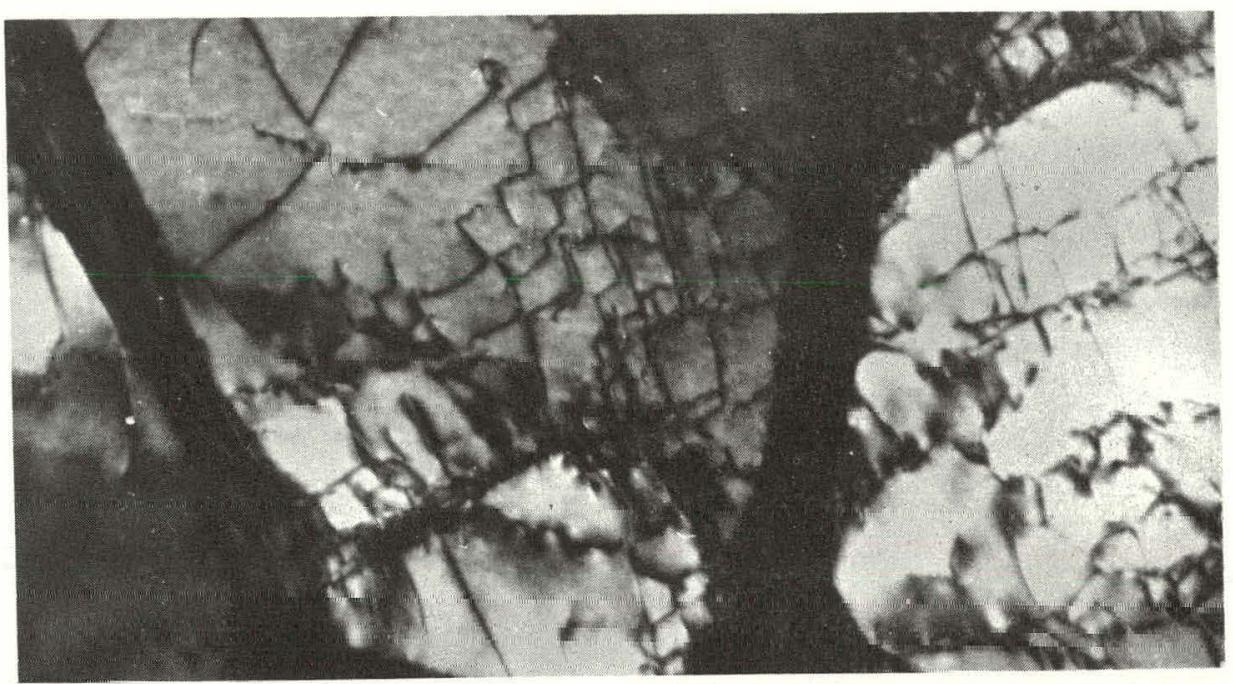

(B)

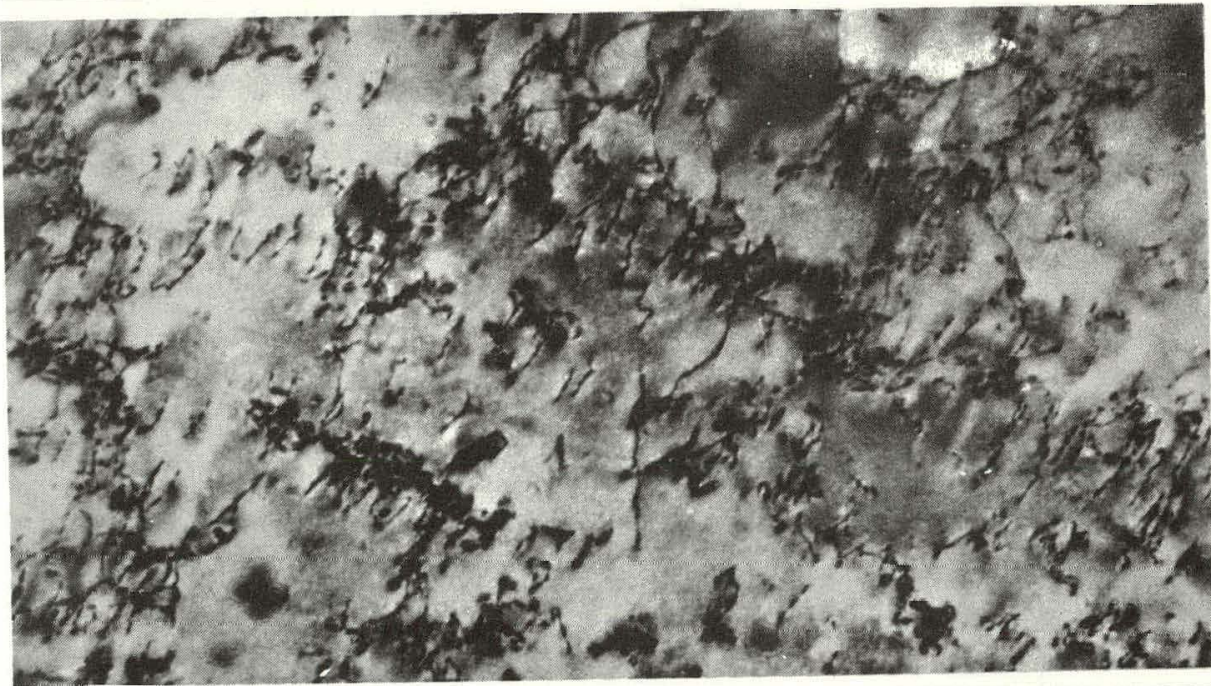

(C)

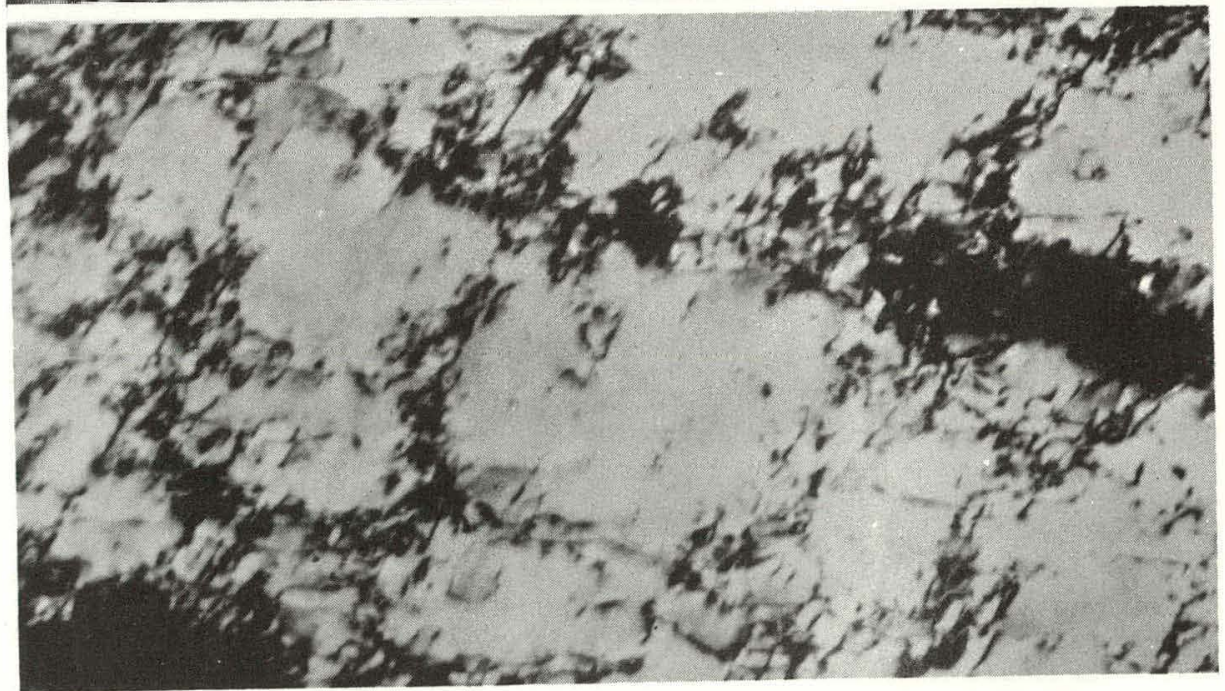

Figure A-2. Effect of Temperature on Dislocation Arrangement After Tensile Deformation. A) $R T \sim 20 \%$ B) $300^{\circ} \mathrm{F} \sim 10 \%$ C) $490^{\circ} \mathrm{F} \sim 15 \%$ 
(A)

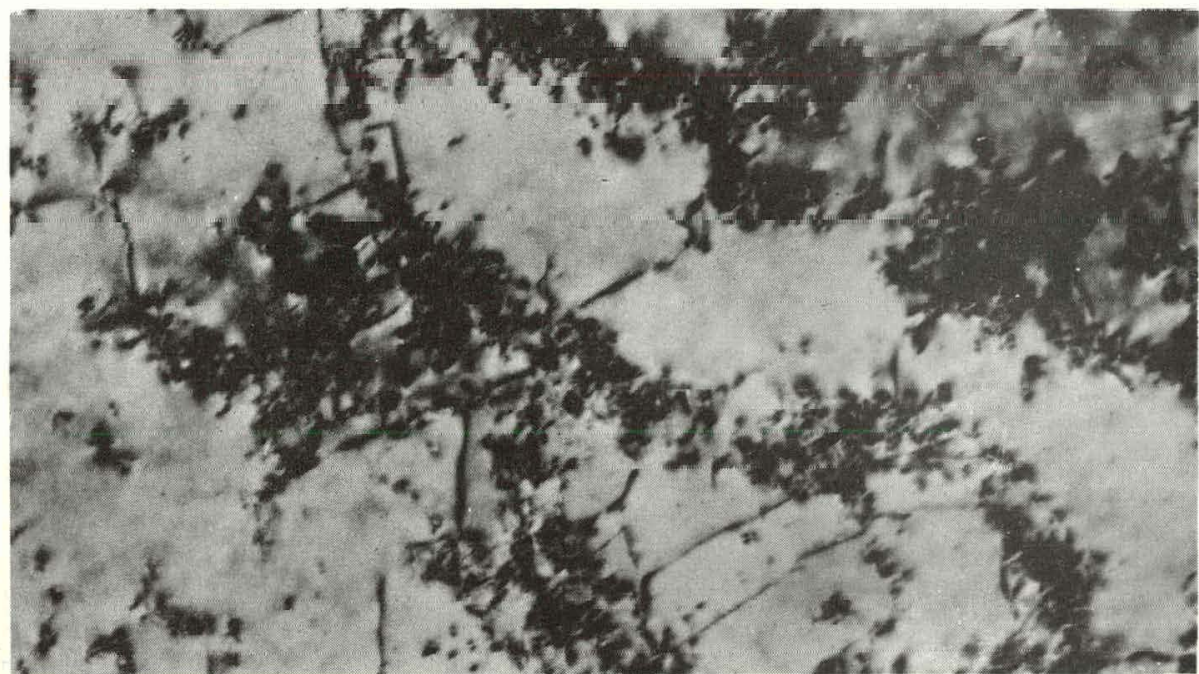

(B)

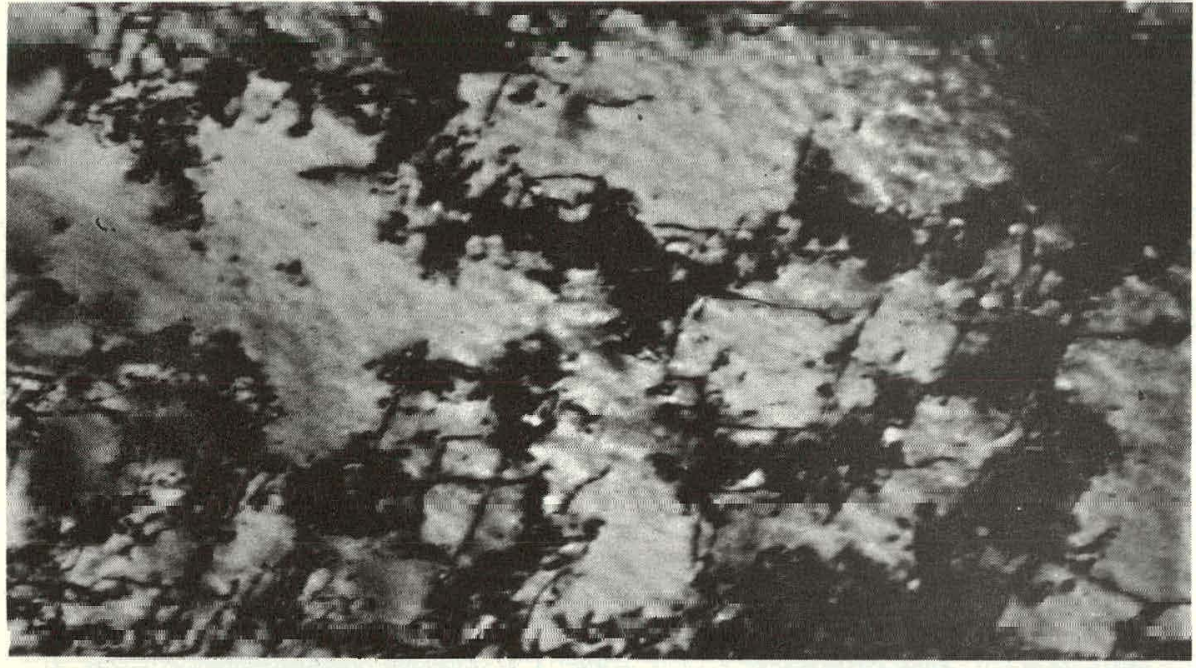

(c)

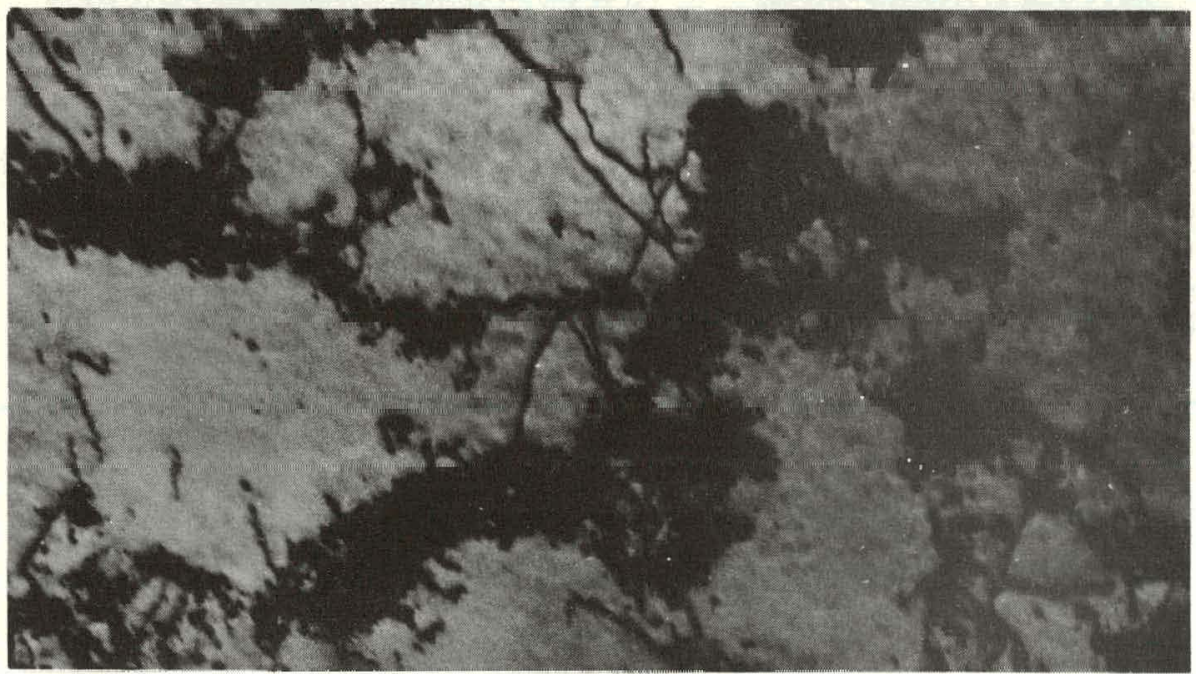

Figure A-3. Cell Formation Following Fatigue at $350^{\circ} \mathrm{F} \mathrm{Al} 37 \mathrm{Cycles}$ at $1.5 \%$ B) 200 Cycles at $0.5 \%$ C) 200 Cycles at $0.38 \%$. 


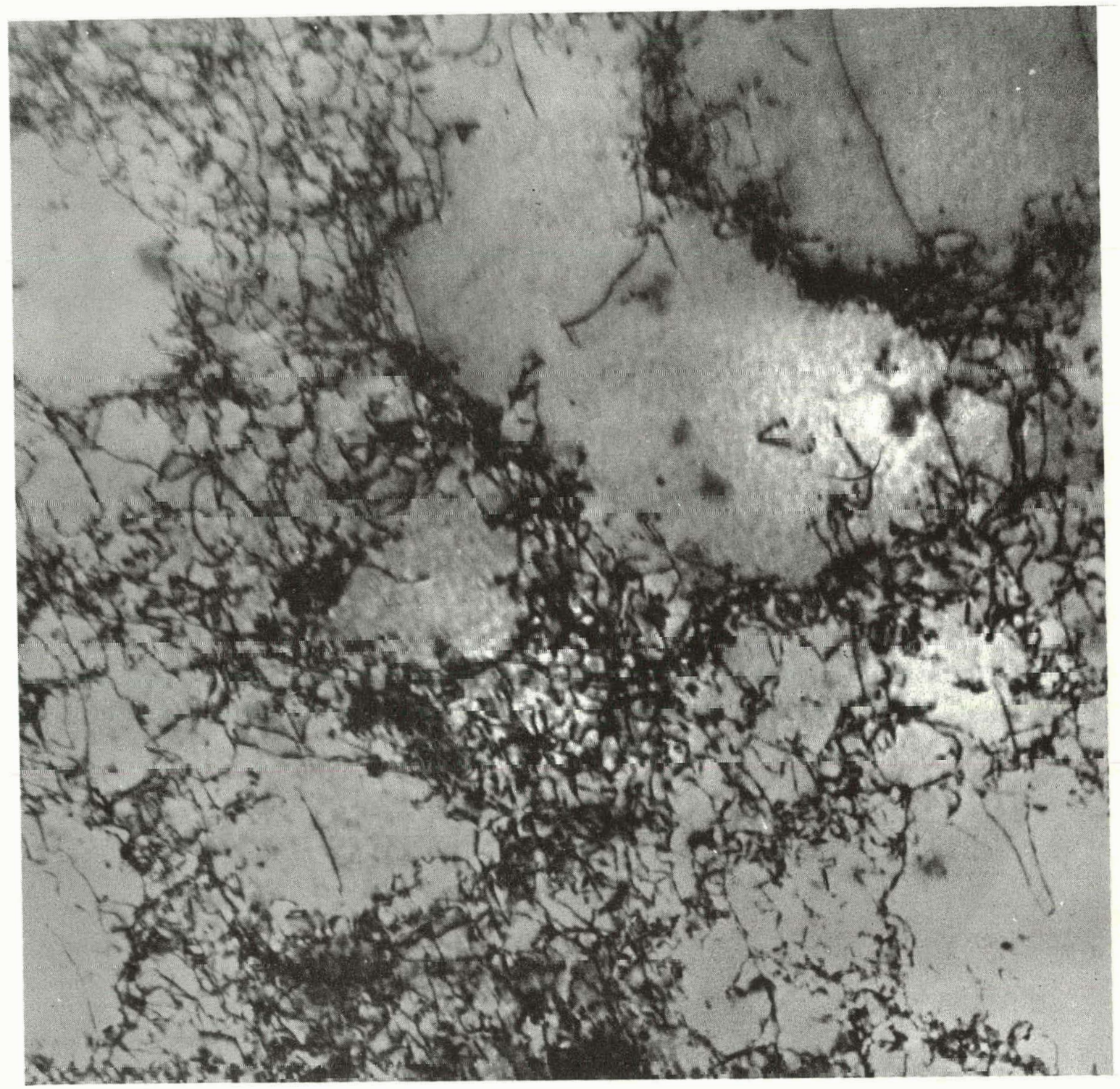

Figure A-4. Cell Formation Following Fatigue at RT for 20 Cycles at $0.5 \%$ 


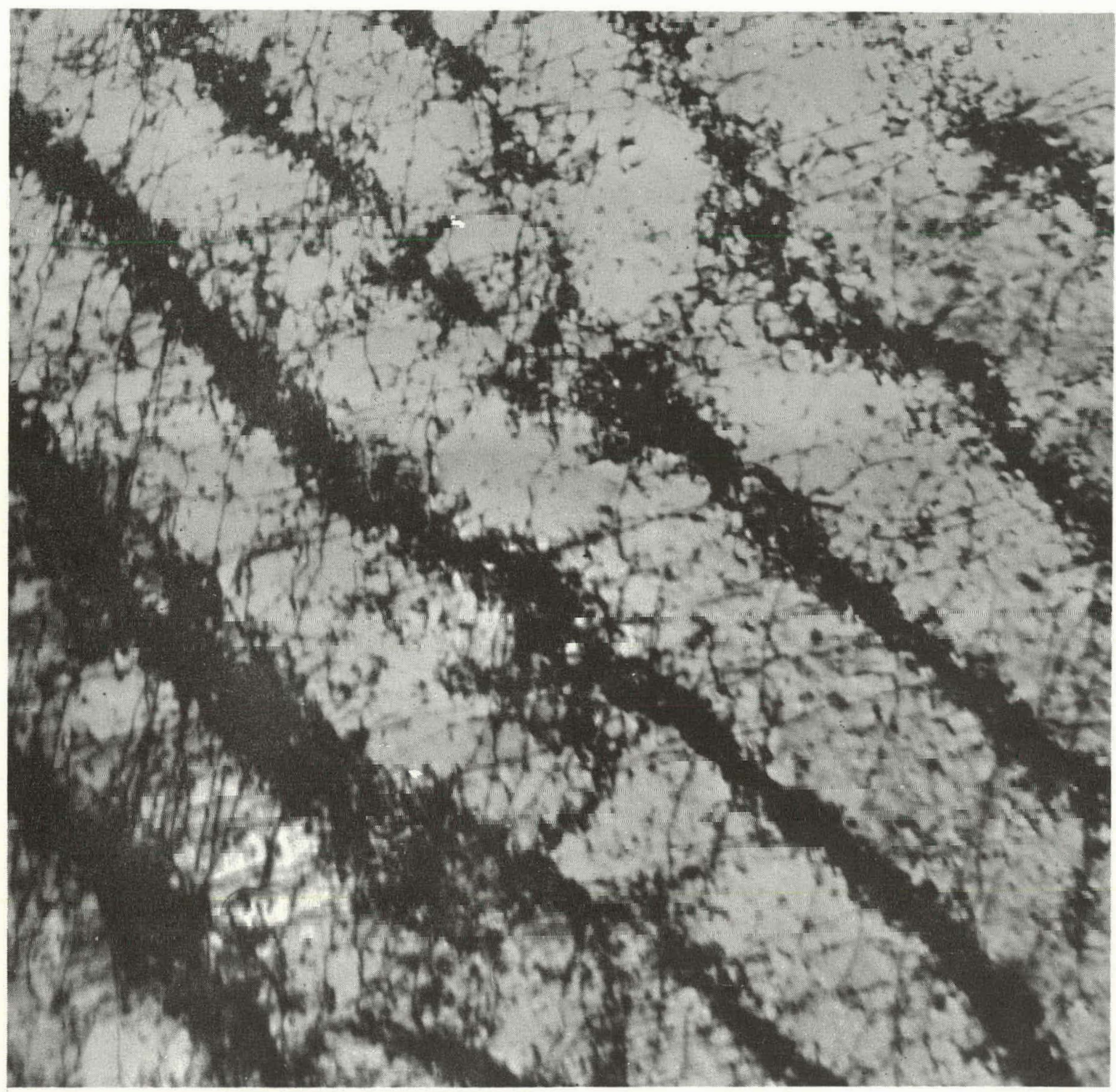

Figure A-5. Elongated Cells Formed After Fatigue at $490^{\circ} \mathrm{F}$ for $200 \mathrm{Cycles}$ at $0.5 \%$

The series of dark bands going diagonally across this micrograph are cell walls containing a high density of dislocations. Within the cells, a much lower density of relatively straight dislocation segments is present. 


\section{DISTRIBUTION}

Aerojet General

Engineering Division

Sacramento Plant

Sacramento, California 95801

Attn. Dr. F.J. Climent

Advisory Committee on Reactor Safeguards

Dr. Spencer H. Bush

Consultant to the Director

Battelle Memorial Institute

Pacific Northwest Lahnratnry

Richland, Washington 99352

Advisory Committee on Reactor Safeguards Mr. Harold Etherington

84 Lighthouse Drive

Jupiter, Florida 33458

Advisory Committee on Reactor Safeguards

Dr. William L. Faith

2540 Huntington Drive

San Marino, California 91108

Advisory Committee on Reactor Safeguards

Dr. Chester P. Siess

Department of Civil Engineering

3129 Civil Engineering Bldg.

University of Illinois

Urbana, Illinois 61801

Advisory Committee on Reactor Safeguards

Dr. Stephen H. Hanauer

Professor of Nuclear Engineering

606 Dougherty Hall

University of Tennessee

Knoxville, Tennessee 37916

Advisory Committee on Reactor Safeguards

Dr. Joseph M. Hendrie

Nuclear Engineering Department

Brookhaven National Laboratory

Upton, New York 11973

Advisory Committee on Reactor Safeguards

Dr. Herbert S. Isbin

Department of Chemical Engineering

University of Minnesota

Minneapolis, Minnesota 55455
1 Advisory Committee on Reactor Safeguards

Mr. Harold G. Mangelsdorf

78 Knollwood Road

Short Hills, New-Jersey 07078

Advisory Committee on Reactor Safeguards

Dr. Harry O. Monson, Senior Engineer

Laboratory Director's Office

Argonne National Laboratory

9700 South Cass Avenue

Argonne, Illinois 60439

Advisory Committee on Reactor Safeguards

1

12421 West Rowland Avenue

Littleton, Colorado 80120

Advisory Committee on Reactor Safeguards

Dr. David Okrent, Senior Physicist

1 Laboratory Director's Office

Argonne National Laboratory

9700 South Cass Avenue

Argonne, Illinois 60439

Advisory Committee on Reactor Safeguards

Dean Nunzio J. Palladino

College of Engineering

The Pennsylvania State University

101 Hammond Building

University Park, Pennsylvania 16802

Advisory Committee on Reactor Safeguards

1 Dr. William R. Stratton

Los Alamos Scientific Laboratory

P. O. Box 1663

Los Alamos, New Mexico 87544

Advisory Committee on Reactor Safeguards

Dr. Carroll W. Zabel

1 Director of Research

University of Houston

Cullen Boulevard

Houston, Texas 77004

Mr. Raymond F. Fraley

3

1

Executive Secretary

Advisory Committee on Reactor Safeguards

U.S. Atomic Energy Commission

Room 1034-H

Washington, D.C. 20545 
Argonne National Laboratory

9700 South Cass Avenue

Argonne, lllinois

Attn: Mr. Paul G. Shewmon ;

Argonne National Laboratory 9700 South Cass Avenue

Argonne, Illinois

Attn: Dr.. P. Lottes

Argonne National Laboratory

9700 South Cass Avenue

Argonne, Illinois

Attn: Dr. C.E. Dickerman

Argonne National Laboratory

9700 South Cass Avenue

Argonne, Illinois

Attn: Dr. R.O. Ivins

Argonne National Laboratory

9700 South Cass Avenue

Argonne, Illinois

Attn: Dr. S. Fistedis

Argonne National Laboratory

9700 South Cass Avenue

Argonne, Illinois

Attn: Dr. R.C. Vogel

Argonne National Laboratory

9700 South Cass Avenue

Argonne, Illinois

Attn: LMFBH Program Otfice

Argonne National Laboratory

9700 South Cass Avenue

Argonne, Illinois

Attn: Mr. A. Amorosi

Argonne National Laboratory

9700 South Cass Avenue

Argonne, Illinois

Attn: Dr. L. Baker

Atomic Energy Commission

Division of Reactor Development and Technology

Washington, D.C. 20545

Attn: Col. R.L. Ednie

Asst. Director for Army Reactors
Atomic Energy Commission

1

Division of Reactor Development and Technology

Washington, D.C. 20545

Attn: Mr. M.A. Rosen

Asst. Director for Plant Engineering

1

Atomic Energy Commission

1

Division of Reactor Development and Technology

Washington, D.C. 20545

Attn: Mr. M.J. Whitman

Asst. Director for Program Analysis

Atomic Energy Commission

1

Division of Reactor Development and Technology

Washington, D.C. 20545

1

Attn: Dr. E.E. Sinclair

Asst. Diiector for Reactor Technoloyy

Atomic Energy Commission

1

Division of Reactor Development and Technology

Washington, D.C. 20545

Attn: Mr. A. Giambusso

Asst. Director for Project Management

Atomic Energy Commission

1

Division of Reactor Development and Technology

Washington, D.C. 20545

Attn: Mr. E.E. Kintner

Asst. Director for Reactor Engineering

1 Atomic Energy Commission

1

Division of Reactor Development and Technology

Washington, D.C. 20545

Attn: Mr. J. W. Crawford

Asst. Director for Engineering Standards

2

Atomic Energy Commission

Division of Compliance, Region IV

10395 West Colfax Avenue

Denver, Colorado 80215

1

Attn: Mr. John W. Flora

Atomic Energy Commission

Division of Compliance

Washington, D.C. 20545

Attn: Mr. L. Kornbllth, Jr.

Atomic Energy Commission 
Atomic Energy Commission

Division of Reactor Standards

Washington, D.C. 20545

Attn: Mr. E.G. Case

$$
\text { Fis }
$$

Atomic Energy Commission

Division of Reactor Standards

Washington, D.C. 20545

Attn: Mr. M. Bolotsky

Atomic Energy Commission

Division of Reactor Standards

Washington, D.C. 20545

Attn: Mr. A.B. Holt

Atomic Energy Commission

Division of Reactor Standards

Washington, D.C. 20545

Attn: Mr. R. Waterfield

Atomic Energy Commission

Division of Reactor Standards

Washington, D.C. 20545

Attn: Dr. G. Burley

Atomic Energy Commission

Division of Reactor Standards

Washington, D.C. 20545

Attn: Mr. R. Impara

Atomic Energy Commission

Water Projects Branch

Division of Reactor Development and Technology

Washington, D.C. 20545

Attn: Mr.W.H. Layman

Atomic Energy Commission

Naval Reactors Branch

Division of Reactor Development ānod Technology

Washington, D.C. 20545

Attn: Mr. R.S. Brodsky

Atomic Energy C.nmmission

Division of Reactor Development and Technology Washington, D.C. 20545

Attn: A.J. Pressesky

Atomic Energy Commission

Division of Reactor Development and Technology

Washington, D.C. 20545

Attn: Mr. S.A. Szawlewicz
Division of Reactor Development and Technology

Washington, D.C. 20545

Attn: Mr. R.R. Newton

1 Atomic Energy Commission

Division of Production

Washington, D.C. 20545

Attn: Mr. George B. Pleat

1 Atomic Energy Commission

c/o Gulf General Atomlc, Inc.

P.O. Box 608

San Diego, California 92112

Attn: Mr. Russell H. Ball

1

Atomics International

P.O. Box 309

Canoga Park, California

Attn: Dr. H. Morewitz

1

Babcock \& Wilcox Company

Washington Operations Office

1725 I Street, N.W.

Washington,D.C. 20006

1

Babcock \& Wilcox Company

P.O. Box 1260

Lynchburg, Virginia

Attn: Mr. Robert Wascher

1

Battelle Memorial Institute

505 King Avenue

Columbus, Ohio 43201

Attn: Dr. D.N. Sunderman

2 Battelle Memorial Institute

505 King Ávenue

Culumbus, Oliio 4j201

Attn: Dr. D.L. Morrison

Battelle Memorial Institute

$7 \quad 505$ King Avenue

Columbus, Ohio 43201

Attn: Mr. S. Paprocki

Battelle Memorial Institute 
Brookhaven National Laboratory Upton, Long Island, New York 11973

Attn: A.W. Castleman

University of California

Institute of Engineering Research

Berkeley, California 94704

Attn: Prof. V.E. Schrock

University of California

Institute of Engineering Research

Berkeley, California 94704

Attn: Prof. H.A. Johnson

Canoga Park Area Office

P.O. Box 591

Canoga Park, California 91305

Attn: Mr. R.L. Morgan RDT Senior Site Rep.

Combustion Engineering, Inc.

Nuclear Division

P.O. Box 500

Windsor, Connecticut 06095

Attn: Mr. M.F. Valerino

Chicago Operations Office

Atomic Energy Commission

9800 South Cass Avenue

Argonne, Illinois 60439

Attn: Mr. D.M. Gardiner

Douglas United Nuclear

Rirhland, Washington ..

Attn: Mr. John Riches

Harvard Air Cleaning Laboratory

Harvard University

665 Huntington Avenue

Boston, Massachusetts 02190

IIT Research Institute

$10 \mathrm{~W}$. 35th Street

Chicago, Illinois 60616

Attn: Dr. T.A. Zaker

IIT Research Institute

10 W. 35th Street

Chicago, Illinois 60616

Attn: Mr. É.V. Gallagher
1 Idaho Operations Office

Atomic Energy Commission

P.O. Box 2108

Idaho Falls, Idaho 83401

1 Attn: Mr. D. Williams

Liquid Metal Engineering Center

1

c/o Atomics International

P.O. Box 309

1 Canoga Park, Califurnia 91304

Attn: R.W. Dickinson

Los Alamos Scientific Laboratory

P.O. Box 1663

1 Los Alamos, New Mexico 87544

Attn: Mr. J.H. Russel, K Division

MPR Associates, Inc.

1

1140 Connecticut Avenue, N.W.

1 Washington, D.C. 20036

Attn: Mr. T. Rockwell III

Chairman AIF Safety Task Force

National Bureau of Standards

Washington, D.C. 20545

1 Attn: Dr. C. Muehlhause

Naval Ordnance Laboratory

White Oak

Sllver Spring, Maryland

$\Delta t$ tn. Mr. James Proctor

1

North Carolina State Univurgity

1

Department of Mechanical Engineering

Raleigh, North Carolina 27607

1 Attn: Prof. M.N. Ozisik

Nuclear Fuels Services

West Valley, New York 14171

1 Oak Ridge Operations Office

Atomic Energy Commission

Oak Ridge, Tennessee 37830

Attn: Mr. W.L. Smalley

Oak Ridge National Laboratory
P.O. Box $Y$.

Oak Ridge, Tennessee 37830

Attn: Mr. Joel Buchanan: 
Chemical Technology Division

Oak Ridge National Laboratory

P.O. Box $Y$

Oak Ridge, Tennessee 37830

Attn: Mr. D. Ferguson

Chemical Technology Division

Oak Ridge National Laboratory

P.O. Box Y

Oạk Ridge, Tennessee 37830

Attn: Mr. R. Blanco

Oak Ridye National Laboratory

P.O. Box Y

Oak Ridge, Tennessee

Attn: HTGR Safety Program Office

Oak Ridge National Laboratory

P.O. Box $Y$

Oak Ridge, Tennessee

Attn: Mr. W. B. Cottrell

Oak Ridge National Laboratory

P.O. Box Y

Oak Ridge, İennessee

Attn: Mr. P. Rittenhouse

Pecifio Northwest Lahnratories

P.O. Box 088

Richland, Washington 99352

Attn: Mr. G. Rogers

Pacific Northwest Laboratories

P.O. Box 999

Rịchland, Washington 99352

Attn: Mr. J.C. Spanner

Pacific Northwest Laboratories

P.O. Box 999

Richland, Washington 99352

Attn: Dr. J. Batch

Pacific Northwest Laboratories

P.O. Box 999

Richland, Washington 99352

Attn: Mr. R. Nightingale

Pacific Northwest Laboratories

P.O. Box 999

Richland, Washington 99352

Attn: Mr. L. Schwendiman
1 Pacific Northwest Laboratories

P.O. Box 999

Richland, Washington 99352

Attn: Mr. E.R. Astley, Mgr. FFTF

Idaho Nuclear Corporation

1

$1 \quad$ P.O. Box 1845

Idaho Falls, Idaho 83401

Attn: Mr. Curt Haire

Idahu Nuclear Cürporation

2 Idaho Falls, Idaho 8340 I

Attn: Mr. S. O. Johnson

Idaho Nuclear Corporation

4 Idaho Falls, Idaho 83401

Attn: Mr. H. L. Coplen

Idaho Nuclear Corporation

1 Idaho Falls, Idaho 83401

Attn: Mr. O. F. Brockett

Idaho Nuclcar Corporation

1 Idaho Fạlls, Iraho 8340!

Attn: Water Reactor Satety Program Office, Mr. G. U. Brıght, Mgr.

Richland Operations Office

P.O. Bux 500

Richland, Washington 99352

Attn: Mr. C. Robinson

Richland Operations Office

P.O. Box 500

Riclilaind, Wrashington 89352

Attn: Mr. A.S. Waterhouse

Richland Operations Office

P.O. Box 500

Richland, Washington yy̆352

Attn: Mr. A. Brunstad

San Francisco Operations Office
Atomic Energy Commission

2111 Bancroft Way

Berkeley. California 9476

Attn: Mr. C.V. Backlund 
Savannah River Laboratories

E.I. duPont deNemours and Company

Aiken, South Carolina 29802

Attn: Mr. A.H. Peters

TRW Inc.

TRW Systems Group

One Space Park

Redondo Beach, California 90278

Attn: Dr. D. B. Langmuir

TRW Inc.

TRW Systems Group

One Space Park

Redondo Beach, California 90278

Attn: Mr. S.M. Zivi

Westinghouse Electric Corporation

Atomic Power Division

P.O. Box 355

Pittsburgh, Pennsylvania 15230

Attn: Mr. R.A. Wiesemann

Westinghouse Electric Corporation

Atomic Power Division

P.O. Box 355

Pittsburgh, Pennsylvania 15230

Attn: Dr. D. Fletcher

Westinghouse Electric Corporation

Atomic Power Division

P.O. Box 355

Pittshurgh, Pennsylvania 15230

Attn: Dr. E. Beckjord

Westinghouse Electric Corporation

P.O. Box 19218

Tampa, Florida 33616

Attn: Mr. A. Lohmeier

Southern Nuclear Engineering, Inc.

P.O. Box 10

Dunedin, Florida 33528

Attn: Mr. Gilbert Brown

Holmes \& Narver, Inc.

828 South Figueroa St.

Los Angeles, Calitornia YU017

Attn: B. Shimizu
1 Mr. Edward T. Wessel

Research and Development Center Westinghouse Electric Corporation Beulah Road, Churchill Boro

Pittsburgh, Pennsylvania 15235

Dr. William E. Cooper

Teledyne Materials Research

303 Bear Hill Road

Waltham, Massachusetts

$1 \quad$ Roger W. Staehle

Metallurgy Department

Ohio State University

Columbus, Ohio

Mr. Ralph Jones

1 Division of Reactor Development U.S. Atomic Energy Commission Washington 25, D.C.

Mr. H.K. Marks

Room 2 N83

1 Department of the Navy Washington, D.C.

H. Thielsch

140 Shaw Avenue

Cranston 5, Rhode Island

Mr. F.M. Moschine

1

Westinghouse Electric Company

Atomic Power Department

P.O. Box 355

Pittsburgh, Pennsylvania 15230

Dr. P. L. Pfenningwerth

Bettis Atomic Power Laboratory

P.O. Box 79

West Mifflin, Pennsylvania 15122

Professor C.E. Taylor

Department of Theoretical and Applied Mechanics University of Illinois

Urbana, Illinois

Mr. E. Beauchamp-Nobbs

1
U.S. Marine Engineering Laboratory

Annapolis, Maryland 
U.S. Atomic Energy Commission

Division of Technical Information Extension

P.O. Box 62

Oak Ridge, Tennessee

U.S. Atomic Energy Commission

Division of Reactor Licensing

Washington, D.C. 20545

Attn: S.S. Pawlicki

USAEC Site Representative

General Electric Company

Surnyvale, California 04086

Attn: Joel Levy, Senior Site Rep.

Mr. B.L. Greenstreet

P.O. Box Y

Oak Ridge National Laboratory

Oak Ridge, Tennessee

Mr. F.J. Witt

P.O. Box Y

ORNL - Oak Ridge, Tennessee

Commonwealth Edison Company

Dresden Nuclear Power Station

Rựral Roure 1

Morris, Illinois 60450

Attn: H.K. Hoyt

Commonwealth Frisnn rompany

System Mechanical and Structural Engineer 72 West Adams Street

Chicago, Illinois 60690

Attn: N.A. Kershaw

United Kingdom Atomic Energy Authority

Reactor Materíals Laboratory

Wigshaw Lane, Culcheth

Warrington, Lancs.

England

Attn: R.W. Nichols

Atomic Energy of Canada Limited

Chalk River Nuclear Laboratories

Chalk River, Ontario, C.anarda

Dr. George Pon

Mr. Robert D. Wylie

Department of Materials Engineering

Southwest Research Institute

8599 Culebra Road

San Antonio, Texas 78228
3

O.A. Kellerman

Institut Fur Reaktorsicherheit

Der Technischen Uberwachungs

Vereine, e.V.

1

5 Koln - Ehrenfeld, Lukasstr. 90

West Germany

C. A. G. Phillips

U.K.A.E.A. Safeguards Division

1 Authority Health \& Safety Branch

Risley, Warrington, Lancashire

England

Knolls Atomic, Power Laboratory

1

P. O. Box 1072

Schenectady, New York 12301

Attn: Dr. Robert A. Barnes

1

Heactor IVlatèrials Branch

1

Metallurgy Division

Naval Research Laboratory

Washington, D. C. 20545

2

Attn: Mr. L. E. Steele

Department of Material Science \& Engineering

1

Hearst Mining Building

University of California

Berkeley. Calịfornia

3 Attn: Mr. William W. Gerberich

United Engineers and Constructors, Inc.

1

1401 Arch Street

Philadelphia, Pennsylvania 19106

Attn: Mr. John Crowley

1

Aryưrilie National Laboratory

9700 South Cass Avenue

Arguinte, Illinois

Attn: Mr, Crạig Cheng

1 AEG Telefunken

AEC Hochhaus Sued

6 Frankfurt/Main 70

West Geirimaany

Attn: Mr. Dieter Ewers

\section{1}

Division of Reactor Development \& Technology 